\title{
Designer policy for carbon and biodiversity co-benefits under global change
}

Carbon payments can help mitigate both climate change and biodiversity decline through the reforestation of agricultural land ${ }^{1}$. However, to achieve biodiversity co-benefits, carbon payments often require support from other policy mechanisms ${ }^{2}$ such as regulation ${ }^{3,4}$, targeting $^{5,6}$, and complementary incentives ${ }^{7,8}$. We evaluated 14 policy mechanisms for supplying carbon and biodiversity co-benefits through reforestation via carbon plantings (CP) and environmental plantings (EP) in Australia's 85.3 Mha agricultural land under global change. The reference policy — uniform payments (bidders are paid the same price) with landuse competition (both CP and EP eligible for payments), targeting carbon, achieved significant carbon sequestration but negligible biodiversity co-benefits. Land-use regulation (only EP eligible) and two additional incentives complementing the reference policy (biodiversity premium, carbon levy) increased biodiversity co-benefits, but inefficiently. Discriminatory payments (bidders are paid their bid price) with land-use competition were efficient, and with multifunctional targeting of both carbon and biodiversity co-benefits increased the biodiversity co-benefits almost 100-fold. Our findings were robust to uncertainty in global outlook, and to key agricultural productivity and land-use adoption assumptions. While these results suggest a clear policy direction, choices remain for society about the amount of carbon and biodiversity co-benefits desired, and the price it is prepared to pay for them.

Market-based incentives are important policy mechanisms for managing land-use and ecosystem services ${ }^{9}$ and can influence land-use decisions by changing price signals or transaction costs in existing markets, or by creating new markets. Carbon markets are a contemporary example of market-based incentives and many have emerged at national and sub-national levels ${ }^{10}$. Other major payment schemes (e.g. China's Grain for Green program ${ }^{11}$, Costa Rica's Payment for Ecosystem Services ${ }^{12}$, the United States' Conservation Reserve Program, Australia's Emissions Reduction Fund, and the international REDD+ mechanism ${ }^{13}$ ) also incentivise the reforestation of cleared land. Although these schemes often prioritise carbon sequestration, there are strong interactions with other environmental goals, especially biodiversity conservation ${ }^{5,13,14}$. 
Many factors can influence the cost-effectiveness (relative value-for-money) and efficiency (degree to which they achieve maximum value-for-money) of policy mechanisms in delivering carbon and biodiversity co-benefits ${ }^{9,15}$. Payment design can substantially affect the efficiency of carbon markets ${ }^{13,16,17}$. Regulation such as land-use planning, safe minimum standards, and codes of practice are often used to limit trade-offs ${ }^{18}$, but may reduce efficiency through imposing uniform practices. Payment targeting ${ }^{5,14}$ and the use of complementary incentives such as premium payments ${ }^{7,8,13}$ can both increase biodiversity co-benefits. While the efficiency and cost-effectiveness of policy mechanisms have been assessed for achieving a range of environmental objectives ${ }^{19,20}$ including carbon and biodiversity co-benefits ${ }^{7,21}$, evaluations have been limited to single mechanisms and/or undertaken for pilot projects at local scales. Large scale, quantitative, comparisons of multiple mechanisms are rare ${ }^{22}$. No evaluations have considered global change, despite the necessity of evidence-based policy that is robust to future uncertainty ${ }^{23}$.

We evaluated the ability of policy mechanisms to supply carbon sequestration and biodiversity co-benefits via reforestation of CP and EP under global change using the LandUse Trade-Offs (LUTO) model ${ }^{7,24}$. CP (fast-growing Eucalyptus monocultures) provide carbon benefits only, while EP (mix of native trees and shrubs) provide both carbon and biodiversity co-benefits. Land-use change was determined by economic competitiveness. We evaluated 12 core policy mechanisms (Figure 1), combinations of two payment schemes (uniform and discriminatory) implemented as reverse auctions, two land-use policies (competition and regulation), and three payment targeting strategies (carbon, biodiversity, and multifunctional). The total costs and benefits of these policy mechanisms were quantified under four global outlooks at levels equivalent to the 2050 carbon price. Sensitivity was assessed at three agricultural productivity and land-use change adoption rates (Table 1). Then for a common budget, the cost-effectiveness and efficiency of policy mechanisms were compared against the reference policy which was consistent with a carbon market price (U-CC, see Figure 1 for key), and a Pareto efficiency frontier representing the maximum joint production of carbon and biodiversity co-benefits achievable for a given budget. We also evaluated the ability of two incentives complementing the reference policy to cost-effectively increase the supply of biodiversity co-benefits. The incentives included a biodiversity premium providing additional targeted payments for EP achieving a 15\% biodiversity target consistent with the Convention on Biological Diversity Aichi Target 15, and a 10\% carbon 
levy imposed on CP revenues with the funds used for biodiversity premium payments for EP. Results are presented for 2050 under M3 Central—-the M3 global outlook with medium agricultural productivity and adoption hurdle rate settings (i.e. $\mathrm{M} 2 \times$ )—with the sensitivity analysis in the Supplementary Results.

$<$ Insert Table 1 about here $>$

$<$ Insert Figure 1 about here $>$

We found that large budgets may be required to fund payment schemes consistent with global outlook carbon prices, potentially motivating large areas of reforestation, and achieving substantial carbon sequestration and biodiversity co-benefits (Figure 1; Supplementary Tables 1 - 4 and Supplementary Figures 1 - 20). Under M3 Central, the cost of the reference policy was 292 \$B ( 7.5\% of projected Australian GDP in $\left.2050^{25}\right)$. Costs varied widely between policy mechanisms, global outlooks, and with agricultural productivity and adoption behaviour assumptions. For example, for the same carbon sequestration and biodiversity cobenefits, discriminatory payment schemes (D-C-C) cost substantially less (222.22 \$B), as the bid price paid to successful landholders was lower than the uniform price. With land-use regulation (U-R-C), less land changed use as EP were less able to compete with agriculture than CP. This translated to a much lower payment scheme cost (11.43 \$B). These results are the first estimates of the total cost of payment schemes that are directly comparable to a carbon price mechanism ${ }^{7}$ and are consistent with the high costs identified for other major national $^{11,12}$ and international reforestation payment schemes ${ }^{13}$.

While carbon payments sequestered substantial amounts of carbon, they achieved negligible biodiversity co-benefits without supporting regulation or diversified targeting. As CP sequestered carbon more cost-effectively than $\mathrm{EP}^{7}$, land-use change was dominated by $\mathrm{CP}$, particularly in the extensive grazing lands in the north-east (Figure 2a). For example, the reference policy sequestered $109.54 \mathrm{MtCO}_{2} \mathrm{yr}^{-1}$ under the 292 \$B budget, but achieved biodiversity co-benefits of only $0.36 \%$ of the maximum amount possible (Figure 1; Supplementary Tables 3 \& 4). This demonstrates the potential of carbon markets to crowd out land-uses with potential to contribute to conservation goals ${ }^{16}$.

$<$ Insert Figure 2 about here $>$ 
Discriminatory payment schemes were more cost-effective than uniform payment schemes (Figure 1). For example, the discriminatory carbon payment scheme with land-use competition (D-C-C) sequestered $133.94 \mathrm{MtCO}_{2} \mathrm{yr}^{-1}$ under the 292 \$B budget-22\% more than the reference policy. These results show that the cost-effectiveness of discriminatory payments, known theoretically ${ }^{20}$ but previously only demonstrated in localised empirical assessments ${ }^{19}$, holds at continental scale. This effect was insensitive to global outlook, landuse regulation, and targeting strategy (Supplementary Figures 1 - 20 and Supplementary Tables 3 \& 4). However, when targeting carbon, discriminatory payments also achieved few biodiversity co-benefits.

Land-use regulation increased biodiversity co-benefits substantially, but with less carbon sequestration (Figure 1; Supplementary Tables 3 \& 4). For example, the uniform payment scheme with land-use regulation targeting carbon (U-R-C) delivered over 62 times more biodiversity co-benefits (22.88\%) but sequestered only around half the carbon (55.79 $\mathrm{MtCO}_{2}$ $\mathrm{yr}^{-1}$ ) as the reference policy given the 292 \$B budget. Regulation had a similar effect under discriminatory payment schemes.

By considering biodiversity in targeting payments, both carbon sequestration and biodiversity co-benefits could be achieved (Figure 1; Supplementary Tables 3 and 4). Under the 292 \$B budget and compared to the reference policy (U-C-C), uniform payments with land-use competition and multifunctional targeting (U-C-M) achieved 84 times the biodiversity cobenefits (30.11\%) and retained around three-quarters of the sequestered carbon (82.89 $\mathrm{MtCO}_{2}$ $\mathrm{yr}^{-1}$ ), whereas biodiversity targeting (U-CR-B) achieved over 113 times the biodiversity cobenefits (40.83\%), but only sequestered around one quarter of the carbon (27.59 $\left.\mathrm{MtCO}_{2} \mathrm{yr}^{-1}\right)$. These results provide evidence that previously observed effectiveness of targeting payments is generalisable $e^{5,6,14}$.

The biodiversity premium and carbon levy also achieved joint carbon and biodiversity cobenefits. The biodiversity premium induced substantial biodiversity gains with a minor impact on carbon sequestration, but at substantial additional cost (Figure 3). Under M3 Central, a premium payment achieving the $15 \%$ biodiversity target via EP cost an additional 47.73 \$B and involved a 14\% reduction in carbon sequestration (94.43 $\mathrm{MtCO}_{2} \mathrm{yr}^{-1}$; Figure 1e). Under a carbon levy, while substantial increases in biodiversity were achieved at low levy rates, higher rates became prohibitive (Figure 4). High levies reduced the 
competitiveness and uptake of CP and hence, the funding available for EP, creating a loselose situation for carbon and biodiversity. We are not aware of any previous findings of these prohibitive disincentive effects in an environmental context. A 10\% carbon levy consistently increased biodiversity co-benefits with modest foregone carbon sequestration across global outlooks, adoption rates, and agricultural productivity rates (Figure 4). Under the 292 \$B budget, this levy achieved 53 times the biodiversity co-benefits (19.09\%) of the reference policy, and sequestered $13 \%$ less carbon (95.46 $\mathrm{MtCO}_{2} \mathrm{yr}^{-1}$ ), with no additional cost. If applied to D-C-C, it is likely that both complementary incentives would achieve co-benefits close to the efficiency frontier. However, the mechanism lacks the flexibility of D-C-M for tailored achievement of co-benefits.

$<$ Insert Figure 3 about here $>$

$<$ Insert Figure 4 about here >

In theory and by design, our model-based implementation of a discriminatory payment scheme with land-use competition generated efficient policy outcomes due to the ability of different land-uses to compete and cost-effectively supply carbon sequestration and biodiversity co-benefits, and to exploit heterogeneous supply costs ${ }^{20,26}$. The Pareto efficiency frontier (Figure 1e) illustrates that by varying the weighting of carbon versus biodiversity objectives in quantifying multifunctionality, efficient trade-offs can be achieved at any point on the frontier. Benchmarking against the frontier, both uniform payments and land-use regulation were inefficient in achieving carbon sequestration and biodiversity co-benefits (Figure 1e). The discriminatory payment scheme with land-use competition and multifunctional targeting (D-C-M) optimally traded-off carbon sequestration and biodiversity co-benefits assuming relative change in each is valued equally by society. Under the 292 \$B budget, D-C-M achieved over 96 times the biodiversity co-benefits (34.70\%) and roughly the same carbon sequestration (108.09 $\mathrm{MtCO}_{2} \mathrm{yr}^{-1}$ ) as the reference policy (Figure 1). D-C-M involved a 17\% larger area of reforestation with 56 times the area of EP concentrated in highbenefit biodiversity areas (Figure $2 b$ ).

A number of caveats apply. Our analyses do not consider activities beyond CP and EP which may offer cost-effective carbon sequestration and /or biodiversity co-benefits such as avoided deforestation, bioenergy crops, or changed agricultural management. While sensitivity of the model to variation in individual parameters such as climate change has been covered 
elsewhere $\mathrm{e}^{7,24,27}$, the results hinge on the substantial difference between the carbon sequestration potential and profitability of CP relative to EP. However, both sensitivity analyses $^{24,27}$ and empirical evidence ${ }^{28}$ suggest that uncertainty within reasonable bounds in these components is unlikely to change the general conclusions. Despite transactions costs being potentially significant ${ }^{19}$, we have omitted them as they are likely to be similar across the policy mechanisms assessed. We acknowledge omission of significant trade-offs for other ecosystem services such as food production and water resources from the analysis, and that reduced Australian agricultural production and export may also create price signals for agricultural development elsewhere, with consequent carbon and biodiversity implications ${ }^{5,10,16}$.

Several implications arise for climate change mitigation and biodiversity conservation policy in Australia and elsewhere. Efficient policy is vital for motivating the widespread reforestation needed to mitigate both climate change and biodiversity loss ${ }^{29}$. While uniform payments, land-use regulation, and complementary incentive mechanisms have been commonly assessed ${ }^{3,4,7}$ and implemented ${ }^{12,15}$, we reveal that discriminatory payment schemes that take advantage of land-use competition and seek multifunctional outcomes are far more cost-effective and could be tailored to efficiently achieve any desired combination of carbon and biodiversity co-benefits. This suggests a clear policy direction for carbon and biodiversity, but also for payments for ecosystem services more broadly, both in Australia and globally. Such policy mechanisms may help improve the cost-effectiveness and efficiency of payment schemes, which have varied considerably ${ }^{9,19}$. However, we emphasise that careful mechanism design and implementation informed by local social, economic, and environmental context is required in practice to realise the gains identified by our modelbased findings ${ }^{9,15,30}$. Sustainably financing large payment schemes will likely require additional, flexible policy mechanisms. Rather than a single-year implementation as assessed herein, a long term approach is warranted spreading investment over several decades to minimise impacts on the wider economy. Ultimately, the level of investment will depend on the levels of carbon sequestration and biodiversity conservation desired by society, and the costs it is willing to pay for them. 


\section{References}

1. Lin, B. B., Macfadyen, S., Renwick, A. R., Cunningham, S. A. \& Schellhorn, N. A. Maximizing the environmental benefits of carbon farming through ecosystem service delivery. Bioscience 63, 793-803 (2013).

2. Bustamante, M., et al. Co-benefits, trade-offs, barriers and policies for greenhouse gas mitigation in the agriculture, forestry and other land use (AFOLU) sector. Global Change Biol. 20, 3270-3290 (2014).

3. Polglase, P. J., et al. Potential for forest carbon plantings to offset greenhouse emissions in Australia: economics and constraints to implementation. Clim. Change 121, 161-175 (2013).

4. Renwick, A. R., et al. Biodiverse planting for carbon and biodiversity on indigenous land. PLoS ONE 9, e91281 (2014).

5. Thomas, C. D., et al. Reconciling biodiversity and carbon conservation. Ecol. Lett. 16, 39-47 (2013).

6. Wunscher, T. \& Engel, S. International payments for biodiversity services: Review and evaluation of conservation targeting approaches. Biol. Conserv. 152, 222-230 (2012).

7. Bryan, B. A., et al. Supply of carbon sequestration and biodiversity services from Australia's agricultural land under global change. Global Environ. Chang. 28, 166181 (2014).

8. Crossman, N. D., Bryan, B. A. \& Summers, D. M. Carbon payments and low-cost conservation. Conserv. Biol. 25, 835-845 (2011).

9. Kinzig, A. P., et al. Paying for Ecosystem Services-Promise and Peril. Science 334, 603-604 (2011).

10. Newell, R. G., Pizer, W. A. \& Raimi, D. Carbon market lessons and global policy outlook. Science 343, 1316-1317 (2014).

11. Liu, J. G., Li, S. X., Ouyang, Z. Y., Tam, C. \& Chen, X. D. Ecological and socioeconomic effects of China's policies for ecosystem services. Proc. Natl. Acad. Sci. USA 105, 9477-9482 (2008).

12. Daniels, A. E., Bagstad, K., Esposito, V., Moulaert, A. \& Rodriguez, C. M. Understanding the impacts of Costa Rica's PES: Are we asking the right questions? Ecol. Econ. 69, 2116-2126 (2010).

13. Busch, J. Supplementing REDD+ with biodiversity payments: the paradox of paying for multiple ecosystem services. Land Econ. 89, 655-675 (2013).

14. Venter, O., et al. Harnessing carbon payments to protect biodiversity. Science 326, 1368- (2009). 
15. Ajayi, O. C., Jack, B. K. \& Leimona, B. Auction design for the private provision of public goods in developing countries: lessons from payments for environmental services in Malawi and Indonesia. World Devel. 40, 1213-1223 (2012).

16. Lindenmayer, D. B., et al. Avoiding bio-perversity from carbon sequestration solutions. Conserv. Lett. 5, 28-36 (2012).

17. Jack, B. K., Kousky, C. \& Sims, K. R. E. Designing payments for ecosystem services: Lessons from previous experience with incentive-based mechanisms. Proc. Natl. Acad. Sci. USA 105, 9465-9470 (2008).

18. Kenward, R. E., et al. Identifying governance strategies that effectively support ecosystem services, resource sustainability, and biodiversity. Proc. Natl. Acad. Sci. USA 108, 5308-5312 (2011).

19. Wunder, S., Engel, S. \& Pagiola, S. Taking stock: A comparative analysis of payments for environmental services programs in developed and developing countries. Ecol. Econ. 65, 834-852 (2008).

20. Polasky, S., Lewis, D. J., Plantinga, A. J. \& Nelson, E. Implementing the optimal provision of ecosystem services. Proc. Natl. Acad. Sci. USA 111, 6248-6253 (2014).

21. Nelson, E., et al. Efficiency of incentives to jointly increase carbon sequestration and species conservation on a landscape. Proc. Natl. Acad. Sci. USA 105, 9471-9476 (2008).

22. Barry, L. E., Yao, R. T., Harrison, D. R., Paragahawewa, U. H. \& Pannell, D. J. Enhancing ecosystem services through afforestation: How policy can help. Land Use Policy 39, 135-145 (2014).

23. Naeem, S., et al. Get the science right when paying for nature's services. Science 347, 1206-1207 (2015).

24. Connor, J. D., et al. Modelling Australian land use competition and ecosystem services with food price feedbacks at high spatial resolution. Environ. Model. Software 69, 141-154 (2015).

25. Hatfield-Dodds, S., et al. CSIRO Australian National Outlook 2015: Technical Report. Canberra, Australia; 2015.

26. Galler, C., von Haaren, C. \& Albert, C. Optimizing environmental measures for landscape multifunctionality: Effectiveness, efficiency and recommendations for agrienvironmental programs. J. Environ. Manage. 151, 243-257 (2015).

27. Gao, L., et al. Sensitivity of parameter sensitivities to scenario choice: Towards robust global sensitivity analysis under deep uncertainty. Environ. Model. Software, (in review).

28. Paquette, A. \& Messier, C. The role of plantations in managing the world's forests in the Anthropocene. Front. Ecol. Environ. 8, 27-34 (2010). 
29. Menz, M. H. M., Dixon, K. W. \& Hobbs, R. J. Hurdles and opportunities for landscape-scale restoration. Science 339, 526-527 (2013).

30. Wunder, S. When payments for environmental services will work for conservation. Conserv. Lett. 6, 230-237 (2013). 


\section{Methods}

\section{Policy mechanisms}

Supplementary Table 5 details the payment schemes, land-use policy, targeting strategies, and complementary incentives assessed in this study.

$<$ Insert Supplementary Table 5 about here $>$

\section{Study area and policy settings}

This analysis was undertaken for the entire intensive agricultural land of Australia-a noncontiguous area of privately-owned and managed cleared land stretching across eastern and southern Australia from Queensland to south-west Western Australia (Supplementary Figure 21). We do not consider potential land-use change in native vegetation, wetland/riparian, or urban areas.

\section{<Insert Supplementary Figure 21 about here $>$}

Agricultural policy in Australia has long been focused on increasing agricultural productivity and competitiveness, and has included relatively low levels of public subsidy. Recent climate policy has included both a price on carbon and direct payments, and bipartisan support exists for land sector contribution to climate change mitigation ${ }^{31}$. Australian biodiversity policy has included many individual incentive schemes for enhancing biodiversity on private land ${ }^{32,33,34}$.

\section{Global outlooks and sensitivity}

We addressed multiple uncertainties using both scenario analysis and sensitivity analysis. To capture the uncertainty in global environmental and economic conditions, we assessed four global outlooks for the period 2013 to 2050 (Supplementary Table 6). Developed through a series of stakeholder interviews and workshops ${ }^{25}$, outlooks are internally-consistent, plausible futures defined by different settings for global action on greenhouse gas emissions abatement, the size of the world economy and human population, and the degree of radiative forcing. Outlooks are benchmarked to the Representative Concentration Pathways (RCPs) ${ }^{35}$. Integrated assessment was undertaken using the Global Integrated Assessment Model $(\mathrm{GIAM})^{25,36}$ to provide projections of key parameters affecting the economic competitiveness 
of land-use including demand for crops and livestock and prices for carbon and oil (Supplementary Figure 22).

<Insert Supplementary Table 6 about here $>$

$<$ Insert Supplementary Figure 22 about here $>$

We undertook a sensitivity analysis across variation in agricultural productivity and land-use change adoption behaviour ${ }^{27}$ (Table 1). Three simple annual increases in agricultural total factor productivity were considered encompassing the range of increases experienced between 1977/78 - 2007/08 in Australia ${ }^{37}$, with the high rate representing a step change increase in productivity. Uncertainty in land-use change adoption behaviour by landholders was captured by three hurdle rates covering the range of variation reported in the land-use change literature ${ }^{38,39,40,41,42}$. Thus, most calculations were performed under each global outlook $o$, adoption hurdle rate $h$, and agricultural productivity rate $u$.

\section{Model pre-calculations}

The core analysis involved substantial spatio-temporal, integrated environmental-economic modelling using the LUTO model ${ }^{7,24}$. The analyses were undertaken using $\sim 1.1 \mathrm{~km}$ resolution raster data (812,383 grid cells) and an annual temporal resolution. Spatio-temporal modelling was conducted with Python ${ }^{43}$ and $\mathrm{NumPy}^{44}$. Model parameters and mathematical notation is summarised in Supplementary Table 7. Bold notation indicates a spatial layer, represented as a vector of grid cells, each with their own individual value for the parameter. Mathematical operations involving spatial layers occurred elementwise (grid-cell-by-grid-cell) unless indicated by square brackets which symbolise operations occurring over all grid cells.

$<$ Insert Supplementary Table 7 about here $>$

\section{Climate change}

Future climate change estimates were modelled at $\sim 1.8^{\circ}$ grid cell resolution using a pattern regression process ${ }^{45}$ based on the outputs of the MPI-ESM-LR general circulation model. These change estimates were used to modify high-resolution, ANUCLIM-interpolated spatial layers of annual mean climate (rainfall and temperature) to create future climate layers for each global outlook. Carbon sequestration and dryland agricultural yields were projected 
under each global outlook based on regressed relationships with annual mean temperature and rainfall ${ }^{7}$. Estimates of changes in water scarcity were also made based on the climate change modelling and used to modify water prices over time.

\section{Carbon sequestration}

We considered carbon stored in accumulated plant biomass following reforestation as our measure of carbon sequestration in metric tonnes of carbon dioxide equivalent (denoted $\mathrm{tCO}_{2}$ ), and did not include changes in soil carbon or agricultural emissions. We used 3-PG2modelled spatial layers of the 20-year carbon sequestration potential $\left(\mathrm{tCO}_{2} \mathrm{ha}^{-1}\right)$ for mixed environmental carbon plantings and hardwood carbon plantings ${ }^{46}$ to model carbon sequestration by EP and CP, respectively. This was converted to 100-year carbon accumulation layers and a growth curve was used to model annual carbon sequestration over time $^{7}$. Carbon sequestration was adjusted for climate change under global outlooks ${ }^{7}$ and reduced by $20 \%$ to account for risk. Carbon sequestration $\overline{\mathbf{c}}(y)_{o}^{f}$ for both reforestation landuses $f$ in $F\{C P, E P\}$ under the four global outlooks $o$ was calculated as the average annual climate- and risk-adjusted rate over the 100-year period multiplied by grid cell area a.

\section{Biodiversity co-benefits}

Biodiversity co-benefits accruing from the establishment of EP were estimated from a continuous biodiversity layer ${ }^{7}$ produced using a generalised dissimilarity model (GDM) ${ }^{47}$. The model related plant species compositional turnover between 325459 site pairs, including over 12000 species of vascular plants, to environmental layers including 11 downscaled, terrain-adjusted climate metrics and 12 soil and substrate metrics at $0.01^{\circ}$ spatial resolution. Compositional turnover was then predicted for each grid cell in response to a change between present day climate (climatic averages for 1985 - 2005) and six 2050 climate futurescombinations of two climate scenarios (RCP 4.5 and RCP 8.5) and three general circulation models (GCMs; Can ESM2, MPI ESM2, and MIROC5). The extent to which EP in each grid cell would increase the representation of vascular plant communities requiring similar environmental conditions within a 1000 km radius was calculated. Higher biodiversity cobenefits were obtained in grid cells that best increase the representation of plant communities under future climate change and have greater landscape connectivity as determined by proximity to remnant habitat and species-area relationships ${ }^{7}$. The final, single biodiversity 
priority score layer $\mathbf{B}^{f}$ was a weighted average of the six climate scenario/GCM combinations calculated using the Limited Degree of Confidence approach ${ }^{48}$ and hence, is robust to uncertainty in future climate change and remains constant over time.

The generic term biodiversity co-benefits $\mathbf{B s}{ }^{f}$ refers to the sum of the area a of each grid cell multiplied by the biodiversity layer $\mathbf{B}^{f}$, divided by the sum of this calculation over all grid cells. $\mathbf{B s}{ }^{f}$ was expressed as a percentage of the maximum possible biodiversity co-benefits achievable by reforesting all agricultural land with EP.

There are several sources of uncertainty in the biodiversity co-benefits of reforestation. While both monoculture plantings and agricultural land may provide ecological benefits ${ }^{49}$, the benefits of CP relative to EP are uncertain and likely to be low. Hence, we assumed that $\mathbf{B s}^{f}=0$ for $f=C P$. However, in practice, uncertainty also exists in the biodiversity cobenefits from EP. Many habitat resources take decades to develop (e.g. tree hollows, fallen boughs, etc.) and many species need to be actively introduced due to a lack of local populations ${ }^{50}$. Tree plantings may even have adverse effects on biodiversity if they replace native grasslands and shrublands or diverse farmland assemblages, or where monocultures preclude future biodiversity co-benefits from active or natural reforestation.

\section{Economic returns}

Economic returns to agriculture were calculated on an annual basis in 2010 Australian dollars as profit at full equity (the economic return to land, capital, and management, exclusive of financial debt) using a profit function ${ }^{51,52,53,54}$. Economic returns were calculated for a set of 23 irrigated and dryland agricultural commodities mapped by ABARES ${ }^{55}$ for the 2005/06 agricultural census year. Yields and commodity prices were sourced from agricultural census data $^{56}$, fixed and variable costs were derived from farm extension handbooks ${ }^{52}$, and water costs from Burns et al. (2011) ${ }^{57}$. Yields of dryland commodities varied over time in response to climate change ${ }^{7}$, commodity prices varied with projected changes in global demand, and the costs of agricultural inputs varied with the price of oil (Supplementary Figure 22). Water price for irrigated agriculture varied in response to changing water scarcity under each global outlook via an elasticity of demand function.

Economic returns to reforestation were calculated on an annual basis over a rolling 100-year horizon from each calendar year $y$ in net present value (NPV) terms to capture uneven costs 
and benefits over time (i.e. high establishment costs and delayed returns). A profit function ${ }^{7,8,58,59}$ was then used to calculate net economic returns to CP and EP each year. CP and EP generated economic returns from the sale of credits for carbon sequestered over time. The carbon price varied over time under each global outlook (Supplementary Figure 22) as modelled by GIAM ${ }^{36}$. The costs of reforestation included upfront, spatially-explicit establishment costs ${ }^{60}$, and uniform annual maintenance and transaction costs (120 \$ ha $\left.{ }^{-1} \mathrm{yr}^{-1}\right)$. We also specified that new areas of reforestation must account for the water used by trees ${ }^{61}$ at the local price of general security entitlements ${ }^{57}$ with water price varying in response to changing water scarcity ${ }^{45}$.

A high discount rate $r=10 \%$ typical of commercial land-use decisions was used throughout. Net present value calculations used year-end discounting such that the present value of a constant annual payment equalled:

$P V(k)=k \times\left(1+\left(1-\frac{1}{(1+r)^{T-1}}\right) / r\right)$

\section{Carbon and biodiversity supply}

Supply of carbon sequestration and biodiversity co-benefits under each policy mechanism were calculated for each year $y$, global outlook $o$, agricultural productivity rate $u$, and adoption hurdle rate $h$. We calculated the discounted carbon sequestration $\mathbf{c}^{P V}(y)_{o}^{f}$ to determine the uniform payment budget outlined below. For this, the annual carbon sequestration (i.e. following the growth curve) $\mathbf{c}(y)_{t, o}^{f}$ for each grid cell over $T=100$ years was discounted to present value:

$\mathbf{c}^{P V}(y)_{o}^{f}=\sum_{t=0}^{T-1} \frac{\mathbf{c}(y)_{t, o}^{f} \times \mathbf{a}}{(1+r)^{t}}$

Each calculation with $f$ superscript was done for $\forall f \in F$ (i.e. CP and EP) unless otherwise indicated. 
We then calculated the total cost of reforestation to the landholder $\mathbf{P}(y)_{h, u, o}^{f}$ for each grid cell including both direct (establishment, maintenance, transaction, and water) costs $\mathbf{T C}(y)_{o}^{f}$ and opportunity costs (foregone net economic returns to agriculture) $\pi(y)_{h, u, o}^{A G}$ in present value terms:

$\mathbf{P}(y)_{h, u, o}^{f}=\mathbf{T C}(y)_{o}^{f}+\boldsymbol{\pi}(y)_{h, u, o}^{A G}$

The breakeven price $\mathbf{p}(y)_{h, u, o}^{f}$ was then determined as the price per unit of carbon sequestration and biodiversity co-benefit in real terms required to change land-use, and its calculation depended on targeting strategy. Under carbon targeting, the breakeven price $\mathbf{p}(y)_{h, u, o}^{f}$ was calculated as the total cost of reforestation $\mathbf{P}(y)_{h, u, o}^{f}$ divided by the discounted carbon sequestration $\mathbf{c}^{P V}(y)_{o}^{f}$ :

$\mathbf{p}(y)_{h, u, o}^{f}=\mathbf{P}(y)_{h, u, o}^{f} / \mathbf{c}^{P V}(y)_{o}^{f}$

Under multifunctional targeting, the break-even price was quantified using an index of multifunctionality $\mathbf{M}(y)_{o}$ which maximised the joint supply of carbon sequestration and biodiversity co-benefits. The index was created by linearly rescaling both the average annual carbon sequestration $\overline{\mathbf{c}}(y)_{o}^{f}$ and biodiversity co-benefits $\mathbf{B s}^{f}$ layers to values between 0 and 5 (represented by the function $L$ ), then calculating the weighted sum:

$\mathbf{M}(y)_{o}^{f}=L\left(\overline{\mathbf{c}}(y)_{o}^{f}\right) \times\left(1-w^{\prime}\right)+L\left(\mathbf{B s}^{f}\right) \times w^{\prime}$

where $w^{\prime}$ is the weight producing the optimal trade-off between carbon sequestration and biodiversity co-benefits. The weight $w^{\prime}$ maximised supply of carbon sequestration and biodiversity co-benefits assuming society values relative change in carbon sequestration the same as relative change in biodiversity co-benefits. To calculate $w^{\prime}$ an indifference curve was specified as the straight line connecting the Pareto frontier (further described in the last section) endpoints - the point that maximises carbon sequestration (i.e. $w=0.000$ ) and the point that maximises biodiversity co-benefits (i.e. $w=1.000$ ). The point on the Pareto frontier 
providing the optimal trade-off between carbon and biodiversity was where the relative marginal change in carbon sequestration equalled the relative marginal change in biodiversity co-benefits. This was the point furthest from the indifference curve and where the slope of the Pareto frontier was equal to the slope of the indifference curve. The weight $w$ ' which produced this optimal trade-off between carbon sequestration and biodiversity co-benefits was then used in the multifunctional targeting strategy (Equation 5).

The breakeven price for multifunctional targeting was then calculated as the total cost of reforestation divided by the index of multifunctionality:

$\mathbf{p}(y)_{h, u, o}^{f}=\mathbf{P}(y)_{h, u, o}^{f} / \mathbf{M}(y)_{o}^{f}$

For biodiversity targeting, the breakeven price was calculated as the total cost of reforestation divided by the biodiversity co-benefits score $\mathbf{B s}^{f}$ :

$\mathbf{p}(y)_{h, u, o}^{f}=\mathbf{P}(y)_{h, u, o}^{f} / \mathbf{B s}^{f}$

For CP, where $\mathbf{B} \mathbf{s}^{f}=0$, the breakeven price $\mathbf{p}(y)_{h, u, o}^{f}$ was set to a large number so that CP would not be selected for payments under biodiversity targeting.

With land-use competition, the most cost-effective reforestation land-use, represented as $\mathbf{x}(y)_{h, u, o}^{f}$ for $\forall f \in F$, was identified for each grid cell as that with the lowest breakeven price:

$\mathbf{x}(y)_{h, u, o}^{C P}=\left\{\begin{array}{l}1 \text { where } \mathbf{p}(y)_{h, u, o}^{C P}<\mathbf{p}(y)_{h, u, o}^{E P} \\ 0 \text { otherwise }\end{array}\right.$

$\mathbf{x}(y)_{h, u, o}^{E P}=\left\{\begin{array}{l}1 \text { where } \mathbf{p}(y)_{h, u, o}^{C P} \geq \mathbf{p}(y)_{h, u, o}^{E P} \\ 0 \text { otherwise }\end{array}\right.$

With land-use regulation, only EP is permitted and Equation 8 is replaced by: 
$\mathbf{x}(y)_{h, u, o}^{C P}=0$

$\mathbf{x}(y)_{h, u, o}^{E P}=1$

Based on this potential land-use change, we then calculated the breakeven price:

$\mathbf{p}(y)_{h, u, o}=\sum_{f \in F}\left(\mathbf{x}(y)_{h, u, o}^{f} \times \mathbf{p}(y)_{h, u, o}^{f}\right)$,

total cost:

$\mathbf{P}(y)_{h, u, o}=\sum_{f \in F}\left(\mathbf{x}(y)_{h, u, o}^{f} \times \mathbf{P}(y)_{h, u, o}^{f}\right)$

discounted carbon sequestration:

$\mathbf{c}^{P V}(y)_{h, u, o}=\sum_{f \in F}\left(\mathbf{x}(y)_{h, u, o}^{f} \times \mathbf{c}^{P V}(y)_{o}^{f}\right)$

average annual carbon sequestration:

$\overline{\mathbf{c}}(y)_{h, u, o}=\sum_{f \in F}\left(\mathbf{x}(y)_{h, u, o}^{f} \times \overline{\mathbf{c}}(y)_{o}^{f}\right)$,

and biodiversity co-benefits:

$\mathbf{B s}(y)_{h, u, o}=\sum_{f \in F}\left(\mathbf{x}(y)_{h, u, o}^{f} \times \mathbf{B s}^{f}\right)$

In constructing supply curves, grid cells were sorted from low to high breakeven price for each of the three targeting strategies (note that in the mathematical expression below, to sort 
grid cells in layer $\mathbf{z}$ by $\mathbf{p}(y)_{h, u, o}$ we write as sort $\left.\left[\mathbf{z}, \mathbf{p}(y)_{h, u, o}\right]\right)$. Carbon sequestration supply was calculated as:

$\operatorname{SC}(y)_{h, u, o}=\operatorname{cumsum}\left[\operatorname{sort}\left[\overline{\mathbf{c}}(y)_{h, u, o}, \mathbf{p}(y)_{h, u, o}\right]\right]$

Biodiversity supply was calculated as:

$\mathbf{S B}(y)_{h, u, o}=\operatorname{cumsum}\left[\operatorname{sort}\left[\mathbf{B s}(y)_{h, u, o}, \mathbf{p}(y)_{h, u, o}\right]\right]$

For the uniform payment scheme, the payment budget required for each grid cell to adopt reforestation $\mathbf{Q}(y)_{h, u, o}$ was calculated as the breakeven price multiplied by the cumulative sum of discounted annual carbon sequestration, both sorted by breakeven price:

$\mathbf{Q}(y)_{h, u, o}=\operatorname{sort}\left[\mathbf{p}(y)_{h, u, o}, \mathbf{p}(y)_{h, u, o}\right] \times \operatorname{cumsum}\left[\operatorname{sort}\left[\mathbf{c}^{P V}(y)_{h, u, o}, \mathbf{p}(y)_{h, u, o}\right]\right]$

Supply curves for the uniform payment scheme thereby present, at each point on the curve, the total cost to government of paying for carbon sequestration from reforestation where the most cost-effective suppliers each receive the price per $\mathrm{tCO}_{2}$ of the highest-priced bid required to supply a given level of carbon sequestration.

For the discriminatory payment scheme, the payment budget required for reforestation $\mathbf{Q}(y)_{h, u, o}$ was equivalent to the cumulative sum of the total cost of adopting that landuse $\mathbf{P}(y)_{h, u, o}$ sorted by breakeven price:

$\mathbf{Q}(y)_{h, u, o}=\operatorname{cumsum}\left[\operatorname{sort}\left[\mathbf{P}(y)_{h, u, o}, \mathbf{p}(y)_{h, u, o}\right]\right]$

Thus, supply curves for the discriminatory payment scheme represent, at each point on the curve, the total cost of paying landholders their opportunity cost, including all future income streams foregone, of adopting reforestation. 
Supply curves were created by plotting the supply of carbon sequestration $\mathbf{S C}(y)_{h, u, o}$ and biodiversity co-benefits $\mathbf{S B}(y)_{h, u, o}$ against the payment budget $\mathbf{Q}(y)_{h, u, o}$ for both uniform and discriminatory payments.

\section{Policy evaluation under global outlooks}

Area, cost, and supply

We first identified those grid cells where the most profitable reforestation land-use (i.e. CP or EP) out-competed agriculture $\boldsymbol{\varphi}(y)_{h, u, o}$ (i.e. where the breakeven price $\mathbf{p}(y)_{h, u, o}$ was less than or equal to the global outlook carbon price $p_{o}$, Supplementary Figure 22):

$\boldsymbol{\varphi}(y)_{h, u, o}=\left\{\begin{array}{l}1 \text { where } \mathbf{p}(y)_{h, u, o} \leq p_{o} \\ 0 \text { otherwise }\end{array}\right.$

The total budget required for each payment scheme was then quantified as the maximum cumulative budget over all reforested grid cells:

$Q(y)_{h, u, o}=\max \left[\operatorname{sort}\left[\boldsymbol{\varphi}(y)_{h, u, o}, \mathbf{p}(y)_{h, u, o}\right] \times \mathbf{Q}(y)_{h, u, o}\right]$

The total area of potential land-use change was calculated as the sum of the area of reforested grid cells a:

$A(y)_{h, u, o}=\operatorname{sum}\left[\boldsymbol{\varphi}(y)_{h, u, o} \times \mathbf{a}\right]$

Carbon sequestration and biodiversity co-benefits supply were calculated as the cumulative supply over all reforested grid cells:

$S C(y)_{h, u, o}=\max \left[\operatorname{sort}\left[\boldsymbol{\varphi}(y)_{h, u, o}, \mathbf{p}(y)_{h, u, o}\right] \times \mathbf{S C}(y)_{h, u, o}\right]$

and 
We then calculated supply of carbon sequestration and biodiversity co-benefits from multifunctional and biodiversity targeting, under both land-use competition and regulation. Budgets were set to that of the equivalent carbon-targeting policy mechanisms. Those grid cells, sorted in order of breakeven price $\mathbf{p}(y)_{h, u, o}$ for each targeting strategy (Equations 4, 6, and 7), were identified where the cumulative payment budget $\mathbf{Q}(y)_{h, u, o}$ (Equation 18) was less than or equal to the equivalent budget $Q(y)_{h, u, o}$ (Equation 20). Hence, we replaced $\boldsymbol{\varphi}(y)_{h, u, o}$ in Equation 19 with:

$\boldsymbol{\varphi}(y)_{h, u, o}=\left\{\begin{array}{l}1 \text { where } \mathbf{Q}(y)_{h, u, o} \leq Q(y)_{h, u, o} \\ 0 \text { otherwise }\end{array}\right.$

We then calculated the cost of uniform and discriminatory payment schemes equivalent to the carbon price of the four global outlooks, with land-use competition and regulation. We also tabulated and compared the area of land-use change, and the supply of carbon sequestration (Equation 22) and biodiversity co-benefits (Equation 23) from these payment schemes under the three targeting strategies.

\section{Biodiversity premium}

The biodiversity premium payment policy was designed to complement the reference policy (U-C-C) and cost-effectively procure biodiversity co-benefits by encouraging EP in areas where CP would otherwise be adopted. Hence, the biodiversity premium payments were limited to those grid cells where CP were the most profitable land-use.

To quantify the biodiversity premium payment required, we first calculated the net present value of economic returns to CP and $\operatorname{EP} \pi(y)_{h, u, o}^{f}$ as the discounted future revenue (discounted carbon sequestration $\mathbf{c}^{P V}(y)_{o}^{f}$ multiplied by carbon price $p_{o}$ ) less the direct costs of reforestation $\mathbf{T C}(y)_{o}^{f}$ : 
$\boldsymbol{\pi}(y)_{o}^{f}=\left(\mathbf{c}^{P V}(y)_{o}^{f} \times p_{o}\right)-\mathbf{T C}(y)_{o}^{f}$

The biodiversity premium payment $\Delta \pi(y)_{h, u, o}$ was equal to the opportunity cost of adopting $\mathrm{EP}^{8}$, calculated as the difference in the net present value of returns between CP and EP:

$\Delta \boldsymbol{\pi}(y)_{h, u, o}=\boldsymbol{\pi}(y)_{o}^{C P}-\boldsymbol{\pi}(y)_{o}^{E P}$ where $\boldsymbol{\delta}(y)_{h, u, o}=1$

Note that Equations 26 - 31 were calculated for grid cells where CP were the most profitable land-use (i.e. $\boldsymbol{\delta}(y)_{h, u, o}=1$ where $\boldsymbol{\varphi}(y)_{h, u, o}=1$ in Equation 19 and $\mathbf{x}(y)_{h, u, o}^{C P}=1$ in Equation 8).

The difference in annual average carbon sequestration between CP and EP $\Delta \overline{\mathbf{c}}(y)_{h, u, o}$ was calculated as:

$\Delta \overline{\mathbf{c}}(y)_{h, u, o}=\overline{\mathbf{c}}(y)_{o}^{C P}-\overline{\mathbf{c}}(y)_{o}^{E P}$ where $\boldsymbol{\delta}(y)_{h, u, o}=1$

We then calculated an index of cost-effectiveness $\mathbf{v}(y)_{h, u, o}$ for prioritising grid cells for biodiversity premium payments:

$\mathbf{v}(y)_{h, u, o}=\Delta \boldsymbol{\pi}(y)_{h, u, o} / \mathbf{B s}^{f}$ where $\boldsymbol{\delta}(y)_{h, u, o}=1$

Grid cells were then sorted by decreasing cost-effectiveness. The budget required for biodiversity premium payments $\mathbf{Q}^{B P}(y)_{h, u, o}$ equalled the cumulative sum of the biodiversity premium payment value over all grid cells eligible for premium payments:

$\mathbf{Q}^{B P}(y)_{h, u, o}=\operatorname{cumsum}\left[\operatorname{sort}\left[\Delta \boldsymbol{\pi}(y)_{h, u, o}, \mathbf{v}(y)_{h, u, o}\right]\right]$ where $\boldsymbol{\delta}(y)_{h, u, o}=1$

Total carbon sequestration supply $\mathbf{S C}(y)_{h, u, o}$ under the biodiversity premium equaled the supply under the uniform carbon payment with land-use competition $S C(y)_{h, u, o}$ (Equation 
22) less the cumulative difference in carbon sequestration between CP and $\operatorname{EP} \Delta \overline{\mathbf{c}}(y)_{h, u, o}$ sorted by cost-effectiveness $\mathbf{v}(y)_{h, u, o}$ such that:

$\operatorname{SC}(y)_{h, u, o}=S C(y)_{h, u, o}-\operatorname{cumsum}\left[\operatorname{sort}\left[\Delta \overline{\mathbf{c}}(y)_{h, u, o}, \mathbf{v}(y)_{h, u, o}\right]\right]$ where $\boldsymbol{\delta}(y)_{h, u, o}=1 \quad 30$

The supply of biodiversity co-benefits $\mathbf{S B}(y)_{h, u, o}$ under the biodiversity premium equalled the supply under the uniform carbon payment with land-use competition $S B(y)_{h, u, o}$ (Equation 23) plus the cumulative increase in biodiversity co-benefits provided by EP Bs ${ }^{f}$ sorted by cost-effectiveness $\mathbf{v}(y)_{h, u, o}$ such that:

$\mathbf{S B}(y)_{h, u, o}=S B(y)_{h, u, o}+\operatorname{cumsum}\left[\operatorname{sort}\left[\mathbf{B s}^{f}, \mathbf{v}(y)_{h, u, o}\right]\right]$ where $\boldsymbol{\delta}(y)_{h, u, o}=1$

The impact of an increasing biodiversity premium payment budget on the supply of carbon sequestration and biodiversity co-benefits was then graphed. As an illustrative example, we examined the impacts of achieving the Convention on Biological Diversity Aichi Goal 15 which advocates for the restoration of $15 \%$ degraded ecosystems. We implemented this as the achievement of $15 \%$ of the maximum biodiversity co-benefits available via EP. We quantified the budget required, the area of reforestation, and the trade-offs for carbon sequestration supply involved in achieving this target.

\section{Carbon levy}

The carbon levy policy mechanism was also designed to complement the reference policy (U$\mathrm{C}-\mathrm{C}$ ) in cost-effectively increasing the supply of biodiversity co-benefits. The carbon levy was applied to the revenue from CP which reduced their profitability relative to EP. The funds raised by the carbon levy were made available for a premium payment for EP, costeffectively targeted to supply biodiversity co-benefits.

We calculated the impacts on carbon and biodiversity of a range of carbon levy rates $i$ in $I\{0$, $1,2, \ldots, 100 \%$. First, the economic returns to CP were calculated under each levy rate $i$ and global outlook $o$ in net present value terms as: 
$\boldsymbol{\pi}(y)_{i, o}^{f}=\left(\mathbf{c}^{P V}(y)_{o}^{f} \times p_{o} \times(1-i)\right)-\mathbf{T C}(y)_{o}^{f}$ where $f=C P$

Economic returns to the most profitable land-use $\boldsymbol{\pi}(y)_{i, h, u, o}^{\max }$ were quantified for each grid cell under each carbon levy rate $i$ :

$\boldsymbol{\pi}(y)_{i, h, u, o}^{\max }=\operatorname{maximum}\left(\boldsymbol{\pi}(y)_{h, u, o}^{A G}, \boldsymbol{\pi}(y)_{i, o}^{C P}, \boldsymbol{\pi}(y)_{o}^{E P}\right)$

The biodiversity premium payment $\Delta \pi(y)_{i, h, u, o}$ required to encourage EP in each grid cell was then calculated as the difference in the net present value of economic returns between EP and the most profitable land-use:

$\Delta \boldsymbol{\pi}(y)_{i, h, u, o}=\boldsymbol{\pi}(y)_{i, h, u, o}^{\max }-\boldsymbol{\pi}(y)_{o}^{E P}$

The carbon levy payable by CP was then calculated as the discounted carbon sequestration of CP multiplied by the global outlook carbon price and the levy rate $i$ :

$\mathbf{L}(y)_{i, h, u, o}=\mathbf{c}^{P V}(y)_{o}^{C P} \times p_{o} \times i \times \mathbf{x}(y)_{i, h, u, o}^{C P}$

where $\mathbf{x}(y)_{i, h, u, o}^{C P}$ indicates grid cells where CP are the most profitable land-use under each carbon levy rate $i$ :

$\mathbf{x}(y)_{i, h, u, o}^{C P}=\left\{\begin{array}{l}1 \text { where } \boldsymbol{\pi}(y)_{i, o}^{C P} \geq \boldsymbol{\pi}(y)_{o}^{E P} \cap \boldsymbol{\pi}(y)_{i, o}^{C P} \geq \boldsymbol{\pi}(y)_{h, u, o}^{A G} \\ 0 \text { otherwise }\end{array}\right.$

We then calculated the impacts on the supply of carbon sequestration and biodiversity cobenefits of a range of carbon levy rates using an integer programming problem formulation. The two binary terms $\mathbf{x}(y)_{i, h, u, o}^{C P}$ and $\mathbf{x}(y)_{i, h, u, o}^{E P}$ which indicate the location of CP and EP, respectively, became the decision variables. The objective was to maximise the total biodiversity co-benefits subject to the total payment budget for EP being less than the total levy funds collected from CP: 
$\operatorname{maximise} \operatorname{sum}\left[\mathbf{x}(y)_{i, h, u, o}^{E P} \times \mathbf{B s}^{f}\right]$

subject to $\operatorname{sum}\left[\Delta \boldsymbol{\pi}(y)_{i, h, u, o} \times \mathbf{x}(y)_{i, h, u, o}^{E P}\right] \leq \operatorname{sum}\left[\mathbf{L}(y)_{i, h, u, o} \times \mathbf{x}(y)_{i, h, u, o}^{C P}\right]$

and $\mathbf{x}(y)_{i, h, u, o}^{C P}+\mathbf{x}(y)_{i, h, u, o}^{E P} \leq 1$

The total carbon sequestration and biodiversity co-benefits under each carbon levy were then graphed across global outlook, agricultural productivity rate, and adoption hurdle rate.

\section{Comparing cost-effectiveness and efficiency of policy mechanisms}

The efficiency of policy mechanisms was assessed by calculating a Pareto efficiency frontier quantifying the maximum possible outcomes for carbon sequestration and biodiversity cobenefits given the budget constraint. Each point on the frontier represents an efficient land use configuration where no change in land use could increase carbon sequestration without decreasing biodiversity co-benefits, and vice-versa. For each weight $w$ in $W\{0.000,0.001$, $0.002, \ldots, 1.000\}$ we calculated the index of multifunctionality (Equation 5) and the breakeven price (Equation 6). With land-use competition, the most cost-effective reforestation option providing the maximum multifunctional outcomes was identified for each cell (Equation 8). We sorted grid cells by breakeven price and calculated the cumulative payment budget required (Equation 18). Areas of reforestation were identified where the aggregate cost was less than the common M3 Central budget (Equation 38). The area of potential land-use change and supply of carbon sequestration and biodiversity co-benefits were calculated using Equations 21 - 23. We then plotted the Pareto efficiency frontier for the set of weights $W$ which formed a trade-off curve between carbon sequestration and biodiversity co-benefits for the given budget constraint.

To compare the cost-effectiveness and efficiency of all 14 policy mechanisms, we assessed the supply of carbon sequestration and biodiversity co-benefits, and the area of potential landuse change for each policy mechanism under a constant budget. The budget constraint was set at the total cost of the uniform carbon payment scheme with land-use competition (i.e. the reference policy U-C-C) in M3 Central— \$292.025B required to achieve the equivalent carbon sequestration and biodiversity co-benefits as the M3 global outlook carbon price. 
Areas were identified where the cumulative payment budget (Equations 17 and 18) $\mathbf{Q}(y)_{h, u, o}$ was less than or equal to $\$ 292.025 B$. We then replaced $\boldsymbol{\varphi}(y)_{h, u, o}$ (Equation 19) with:

$\boldsymbol{\varphi}(y)_{h, u, o}=\left\{\begin{array}{l}1 \text { where } \mathbf{Q}(y)_{h, u, o} \leq 292.025 \mathrm{~B} \\ 0 \text { otherwise }\end{array}\right.$

and calculated the area of potential land-use change and supply of carbon sequestration and biodiversity co-benefits supply using Equations 21 - 23. Supply of carbon sequestration and biodiversity co-benefits from each policy mechanism were then plotted against the efficiency frontier. 


\section{References}

31. DCCEE. Securing a clean energy future: the Australian Government's climate change plan. Canberra, Australia: Department of Climate Change and Energy Efficiency, Commonwealth of Australia; 2011.

32. Hajkowicz, S. The evolution of Australia's natural resource management programs: Towards improved targeting and evaluation of investments. Land Use Policy 26, 471478 (2009).

33. Connor, J. D., Ward, J. R. \& Bryan, B. Exploring the cost effectiveness of land conservation auctions and payment policies. Aust. J. Agric. Resour. Econ. 52, 303-319 (2008).

34. Higgins, V., Dibden, J. \& Cocklin, C. Market instruments and the neoliberalisation of land management in rural Australia. Geoforum 43, 377-386 (2012).

35. van Vuuren, D., et al. The representative concentration pathways: an overview. Clim. Change 109, 5-31 (2011).

36. Newth, D., Cai, Y., Finnigan, J., Harman, I. \& Grigg, N. The Shrinking Space for Climate Mitigation: CSIRO, Canberra, 2015.

37. Nossal, K. \& Sheng, Y. Productivity growth: Trends, drivers and opportunities for broadacre and dairy industries. Australian Commodities 17, 216-230 (2010).

38. Dumortier, J. The effects of uncertainty under a cap-and-trade policy on afforestation in the United States. Environ. Res. Lett. 8, 044020 (2013).

39. Murray-Rust, D., Rieser, V., Robinson, D. T., Milicic, V. \& Rounsevell, M. Agentbased modelling of land use dynamics and residential quality of life for future scenarios. Environ. Model. Software 46, 75-89 (2013).

40. Prestemon, J. P. \& Wear, D. N. Linking harvest choices to timber supply. For. Sci. 46, 377-389 (2000).

41. Schroter, D., et al. Ecosystem service supply and vulnerability to global change in Europe. Science 310, 1333-1337 (2005).

42. Richards, K. R. \& Stokes, C. A review of forest carbon sequestration cost studies: A dozen years of research. Clim. Change 63, 1-48 (2004).

43. van Rossum, G. \& the Python community. The Python Programming Language: Version 2.7.5. The Python Software Foundation; 2013.

44. Jones, E., Oliphant, T., Peterson, P., SciPy community, . SciPy: Open Source Scientific Tools for Python. http://www.scipy.org. . 2001.

45. Harman, I. A brief guide to the pattern data within the ICP-ANO process. CSIRO, Canberra; 2013. 
46. Polglase, P., et al. Regional Opportunities for Agroforestry Systems in Australia. Rural Industries Research and Development Corporation: Canberra, 2008.

47. Ferrier, S., Manion, G., Elith, J. \& Richardson, K. Using generalized dissimilarity modelling to analyse and predict patterns of beta diversity in regional biodiversity assessment. Divers. Distrib. 13, 252-264 (2007).

48. McInerney, D., Lempert, R. \& Keller, K. What are robust strategies in the face of uncertain climate threshold responses? Robust climate strategies. Clim. Change 112, 547-568 (2012).

49. Smith, F. P. Assessing the habitat quality of oil mallees and other planted farmland vegetation with reference to natural woodland. Ecol. Manage. Restor. 10, 217-227 (2009).

50. Cunningham, S. C., et al. Balancing the environmental benefits of reforestation in agricultural regions. Perspect. Plant Ecol. Evol. Syst. 17, (2015).

51. Bryan, B. A., Hajkowicz, S., Marvanek, S. \& Young, M. D. Mapping economic returns to agriculture for informing environmental policy in the Murray-Darling Basin, Australia. Environ. Model. Assess. 14, 375-390 (2009).

52. Marinoni, O., et al. Development of a system to produce maps of agricultural profit on a continental scale: An example for Australia. Agric. Syst. 105, 33-45 (2012).

53. Bryan, B. A., King, D. \& Ward, J. R. Modelling and mapping agricultural opportunity costs to guide landscape planning for natural resource management. Ecol. Indicators 11, 199-208 (2011).

54. Hajkowicz, S. \& Young, M. Costing yield loss from acidity, sodicity and dryland salinity to Australian agriculture. Land Degrad. Dev. 16, 417-433 (2005).

55. ABARES. Land Use of Australia, Version 4, 2005-06 dataset. Australian Bureau of Agricultural and Resource Economics. Canberra, Australia; 2010.

56. Australian Bureau of Statistics. Small Area of Agricultural Commodity Data 2005-06. Australian Bureau of Statistics: Canberra, 2006.

57. Burns, K., Hug, B., Lawson, K., Ahammad, H. \& Zhang, K. Abatement potential from reforestation under selected carbon price scenarios. Australian Bureau of Agricultural and Resource Economics and Sciences: Canberra, 2011.

58. Bryan, B. A. \& Crossman, N. D. Impact of multiple interacting financial incentives on land use change and the supply of ecosystem services. Ecosystem Services 4, 60-72 (2013).

59. Paterson, S. E. \& Bryan, B. A. Food-carbon trade-offs between agriculture and reforestation and the efficiency of market-based policies. Ecol. Soc. 17, 21 (2012). 
60. Summers, D. M., Bryan, B. A., Nolan, M. \& Hobbs, T. J. The costs of reforestation: A spatial model of the costs of establishing environmental and carbon plantings. Land Use Policy 44, 110-121 (2015).

61. van Dijk, A. I. J. M. \& Renzullo, L. J. Water resource monitoring systems and the role of satellite observations. HESS 15, 39-55 (2011).

\section{Corresponding author details}

Correspondence and requests for materials should be addressed to:

Dr. Brett A. Bryan

brett.bryan@csiro.au

Waite Campus, Urrbrae, SA 5064 AUSTRALIA

Ph. +61 883038581

\section{Acknowledgements}

The authors are grateful to the Centre for Environmental and Economic Decisions and the National Environmental Research Program for funding two national workshops in which much of this paper was conceived. We are also grateful for the support of our individual organisations, especially CSIRO Agriculture and Australian National Outlook initiative.

\section{Statement of author contributions}

BB, TC, EL, RC, KW conceived and designed the experiments, BB performed the experiments, all authors analyzed the data, BB, MN contributed materials/analysis tools, BB, RR, TC, MP, SC, MK, EL, AR, SE, RC, KW wrote the paper. 


\section{Figure legends}

Figure 1 - Supply of, and trade-offs between, carbon sequestration and biodiversity cobenefits for different policy mechanisms. Colours in the figure key relate to all panels. Supply curves for the 12 core policy mechanisms in panels a - $\mathrm{d}$ are for M3 Central, with supply curves for all four global outlooks, including sensitivity to agricultural production and adoption behaviour assumptions, presented in Supplementary Figures 1 - 20. In panel e trade-offs are presented for each policy under a common budget equal to that of the reference policy in M3 Central (U-C-C, 292 \$B). The Pareto efficiency frontier (dark dotted line) identifies the maximum carbon and biodiversity co-benefits achievable for the budget and the trade-offs between them. White numbers within marker symbols indicate the total area of reforestation in Mha $(\mathrm{CP}+\mathrm{EP}) .{ }^{\mathrm{a}}$ Uniform payments with land-use competition and regulation targeting biodiversity were equivalent, with both coded U-CR-B. ${ }^{\mathrm{b}}$ Discriminatory payments with land-use competition and regulation targeting biodiversity were equivalent, with both coded D-CR-B. (Figure sizing - 1 column width)

\section{Figure 2 - Potential land-use change under the reference policy (a) and the optimal} policy (b) under M3 Central and a budget of 292 \$B. The reference policy (U-C-C) is a uniform payment scheme with land-use competition targeting carbon. The optimal policy (DC-M) is a discriminatory payment scheme with land-use competition and multifunctional targeting. Overall, the spatial arrangement of land-use change depends on the relative profitability of agriculture, CP, and EP. Under both policies land-use change was concentrated in the north-east of the study area due to the relatively low agricultural profitability in these extensive beef cattle grazing lands, and a climate conducive to carbon sequestration. In the optimal policy, EP were more widely distributed but were prominent in southern Australia where biodiversity co-benefits could be cost-effectively achieved. (Figure sizing - 1 column width)

Figure 3 - Cost of a biodiversity premium payment and impact on the supply of carbon sequestration and biodiversity co-benefits. The $\$ 0$ premium payment points indicate the supply achieved under the reference policy (U-C-C) under each global outlook (Supplementary Table 3). The colour of the dots indicates the additional cost of the biodiversity premium payments compared to the reference policy. The figure illustrates the high cost and carbon trade-offs involved in achieving biodiversity co-benefits through a 
premium payment. Uncertainty is presented across global outlooks, and agricultural productivity (L, M, H) and adoption behaviour $(1 \times, 2 \times, 5 \times)$ assumptions. (Figure sizing -1 column width)

Figure 4 - Impact of a carbon levy on carbon sequestration and biodiversity co-benefits.

The carbon levy is applied to the reference scenario (U-C-C). The figure illustrates the increasing biodiversity co-benefits and carbon trade-offs associated with lower levy rates and the prohibitive nature of high levy rates resulting in a lose-lose situation for carbon sequestration and biodiversity co-benefits. Uncertainty is presented across global outlooks, and agricultural productivity (L, M, H) and adoption behaviour $(1 \times, 2 \times, 5 \times)$ assumptions. (Figure sizing - 1 column width) 


\section{Tables}

Table 1 - General description of the global outlooks and key dimensions of the sensitivity analysis. GDP refers to Gross Domestic Product, RCP refers to Representative Concentration Pathway, and PD refers to peak-decline. (Table sizing - 1 column width)

\begin{tabular}{|c|c|c|c|c|c|}
\hline \multicolumn{6}{|c|}{ Global outlooks } \\
\hline $\begin{array}{l}\text { Global } \\
\text { outlook }\end{array}$ & $\begin{array}{l}\text { Climate } \\
\text { change } \\
\text { (warming } \\
\text { by 2100) }\end{array}$ & $\begin{array}{l}\text { Global } \\
\text { abatement } \\
\text { effort }\end{array}$ & $\begin{array}{l}\text { Popu- } \\
\text { lation }\end{array}$ & $\begin{array}{l}\text { GDP } \\
\text { per } \\
\text { capita }\end{array}$ & RCP \\
\hline $\mathbf{L 1}$ & $1.3-1.9^{\circ} \mathrm{C}$ & Very strong & Low & High & 3-PD \\
\hline M3 & $2.0-3.0^{\circ} \mathrm{C}$ & Strong & High & Low & 4.5 \\
\hline M2 & $2.0-3.0^{\circ} \mathrm{C}$ & Modest & Medium & Medium & 4.5 \\
\hline H3 & $4.0-6.1^{\circ} \mathrm{C}$ & None & High & Low & 8.5 \\
\hline \multicolumn{6}{|c|}{ Agricultural productivity } \\
\hline $\mathbf{L}$ & \multicolumn{5}{|c|}{$0 \%$ p.a. simple increase in total factor productivity } \\
\hline $\mathbf{M}$ & \multicolumn{5}{|c|}{$1.5 \%$ p.a. simple increase in total factor productivity } \\
\hline $\mathbf{H}$ & \multicolumn{5}{|c|}{ 3.0\% p.a. simple increase in total factor productivity } \\
\hline \multicolumn{6}{|c|}{ Land-use change adoption hurdle rate } \\
\hline $1 \times$ & \multicolumn{5}{|c|}{$\begin{array}{l}\text { Land-use changes to the most profitable reforestation land- } \\
\text { use when it becomes more profitable than agriculture }\end{array}$} \\
\hline $2 \times$ & \multicolumn{5}{|c|}{$\begin{array}{l}\text { Land-use changes to the most profitable reforestation land- } \\
\text { use when it becomes more than twice as profitable as } \\
\text { agriculture }\end{array}$} \\
\hline $5 \times$ & \multicolumn{5}{|c|}{$\begin{array}{l}\text { Land-use changes to the most profitable reforestation land- } \\
\text { use when it becomes more than five times as profitable as } \\
\text { agriculture }\end{array}$} \\
\hline
\end{tabular}




\section{Supplementary Figure Legends}

Supplementary Figure 21 - Location and extent of and broad land-use within the study area. (Figure sizing - full page width).

Supplementary Figure 22 - Prices output from GIAM modelling for the four global outlooks used as input into land-use modelling. (Figure sizing - 1 column width) 


\section{Supplementary Tables}

\section{Supplementary Table 5 - Description of policy mechanisms analysed in this study.}

\begin{tabular}{|c|c|c|}
\hline $\begin{array}{l}\text { Policy } \\
\text { mechanism }\end{array}$ & Type & Description \\
\hline \multirow[t]{2}{*}{$\begin{array}{l}\text { Payment } \\
\text { scheme }\end{array}$} & Uniform & $\begin{array}{l}\text { Reverse auction where the most cost-effective suppliers receive } \\
\text { the same payment for carbon sequestration }\left(\$ \mathrm{tCO}_{2}^{-1}\right) \text { and } \\
\text { biodiversity co-benefits ( } \$ \text { per } \% \text { of maximum). }\end{array}$ \\
\hline & Discriminatory & $\begin{array}{l}\text { Reverse auction where the most cost-effective suppliers receive a } \\
\text { payment equivalent to their cost of supply of carbon sequestration } \\
\left.\text { ( } \$ \mathrm{tCO}_{2}^{-1}\right) \text { and biodiversity co-benefits ( } \$ \text { per } \% \text { of maximum). }\end{array}$ \\
\hline \multirow{2}{*}{$\begin{array}{l}\text { Land-use } \\
\text { policy }\end{array}$} & Competition & Both CP and EP eligible for payments. \\
\hline & Regulation & EP only eligible for payments. \\
\hline \multirow[t]{3}{*}{$\begin{array}{l}\text { Targeting } \\
\text { strategy }\end{array}$} & Carbon & $\begin{array}{l}\text { Payments spatially targeted by cost-effectiveness at supplying } \\
\text { carbon sequestration (payment required per tonne of carbon } \\
\text { sequestration). }\end{array}$ \\
\hline & Multifunctional & $\begin{array}{l}\text { Payments spatially targeted by cost-effectiveness at supplying } \\
\text { both carbon sequestration and biodiversity co-benefits weighted to } \\
\text { achieve optimal levels (payment required per multifunctional } \\
\text { unit). }\end{array}$ \\
\hline & Biodiversity & $\begin{array}{l}\text { Payments spatially targeted by cost-effectiveness at supplying } \\
\text { biodiversity co-benefits (payment required per unit of biodiversity } \\
\text { co-benefit). }\end{array}$ \\
\hline \multirow[t]{2}{*}{$\begin{array}{l}\text { Complementary } \\
\text { incentives }\end{array}$} & $\begin{array}{l}\text { Biodiversity } \\
\text { premium }\end{array}$ & $\begin{array}{l}\text { Additional premium payment to landholders undertaking EP in } \\
\text { areas where CP would have otherwise been adopted. Payments } \\
\text { equalled the difference between returns to EP and the most } \\
\text { profitable land-use and were targeted to cost-effectively achieve } \\
\text { biodiversity co-benefits. }\end{array}$ \\
\hline & Carbon levy & $\begin{array}{l}\text { A levy (\%) on the revenue from CP was imposed and the funds } \\
\text { used as a biodiversity premium payment. }\end{array}$ \\
\hline
\end{tabular}


Supplementary Table 6 - Properties of the global outlooks ${ }^{7,25,36}$.

\begin{tabular}{|c|c|c|c|c|c|c|}
\hline \multirow{2}{*}{ Indicator } & \multirow{2}{*}{ Units } & \multirow{2}{*}{$\begin{array}{l}\text { Value } \\
\text { in } \\
2010\end{array}$} & \multicolumn{4}{|c|}{ Global outlook } \\
\hline & & & L1 & M3 & M2 & Н3 \\
\hline $\begin{array}{l}\text { Population } \\
\text { outlook }\end{array}$ & & - & 1 & 3 & 2 & 3 \\
\hline $\begin{array}{l}\text { Climate change } \\
\text { outlook }\end{array}$ & & - & $\mathrm{L}$ & M & M & $\mathrm{H}$ \\
\hline $\begin{array}{l}\text { Population in } \\
2050\end{array}$ & $\begin{array}{l}\text { Billion } \\
\text { people }\end{array}$ & 6.9 & 8.1 & 10.6 & 9.3 & 10.6 \\
\hline $\begin{array}{l}\text { World GDP per } \\
\text { capita in } 2050\end{array}$ & $\begin{array}{l}\text { US\$ } \\
\text { c000 } \\
2050 \\
\text { cap }^{-1}\end{array}$ & 8.8 & 20.0 & 18.6 & 19.3 & 18.6 \\
\hline $\begin{array}{l}\text { World GDP in } \\
2050\end{array}$ & $\begin{array}{l}\text { US\$ } \\
\text { trillion }\end{array}$ & 61.0 & 161.6 & 197.0 & 179.1 & 197.8 \\
\hline \begin{tabular}{|l} 
Benchmark \\
Representative \\
Concentration \\
Pathway (RCP) \\
\end{tabular} & & - & RCP3-PD & RCP4.5 & RCP4.5 & RCP8.5 \\
\hline $\begin{array}{l}\text { Radiative forcing } \\
\text { in } 2100\end{array}$ & $\mathrm{Wm}^{-2}$ & - & \begin{tabular}{|c|} 
Peak at 3.0 \\
then decline to \\
2.6
\end{tabular} & 4.5 & 4.5 & 8.5 \\
\hline $\begin{array}{l}\text { Atmospheric } \\
\text { concentration in } \\
2100\end{array}$ & $\begin{array}{l}\mathrm{Ppm} \\
\mathrm{CO}_{2}\end{array}$ & - & $\begin{array}{c}445 \\
\text { (declining) }\end{array}$ & $\begin{array}{c}650 \\
\text { (stable) }\end{array}$ & $\begin{array}{c}650 \\
\text { (stable) }\end{array}$ & 1370 (rising) \\
\hline $\begin{array}{l}\text { Greenhouse gas } \\
\text { emissions } 2007 \text { - } \\
2050\end{array}$ & $\mathrm{Gt} \mathrm{CO} 2$ & - & 1437 & 2091 & 2091 & 2823 \\
\hline $\begin{array}{l}\text { Emissions per } \\
\text { capita in } 2050\end{array}$ & $\mathrm{tCO}_{2}$ & 7.0 & 2.2 & 4.7 & 5.4 & 8.7 \\
\hline $\begin{array}{l}\text { Coverage of } \\
\text { greenhouse gas } \\
\text { abatement policy }\end{array}$ & & - & All sources & $\begin{array}{c}\text { All, excluding } \\
\text { emissions } \\
\text { from livestock }\end{array}$ & \begin{tabular}{|c|} 
All, excluding \\
emissions \\
from livestock
\end{tabular} & No sources \\
\hline $\begin{array}{l}\text { Global } \\
\text { abatement effort }\end{array}$ & & - & Very strong & Strong & Modest & No action \\
\hline $\begin{array}{l}\text { Temperature } \\
\text { change in } 2050 \\
\text { relative to } 2007\end{array}$ & $\begin{array}{l}2.0 \\
1.5 \\
1.0 \\
0.5 \\
0.0 \\
{ }^{\circ} \mathrm{C}\end{array}$ & & & & & \\
\hline
\end{tabular}




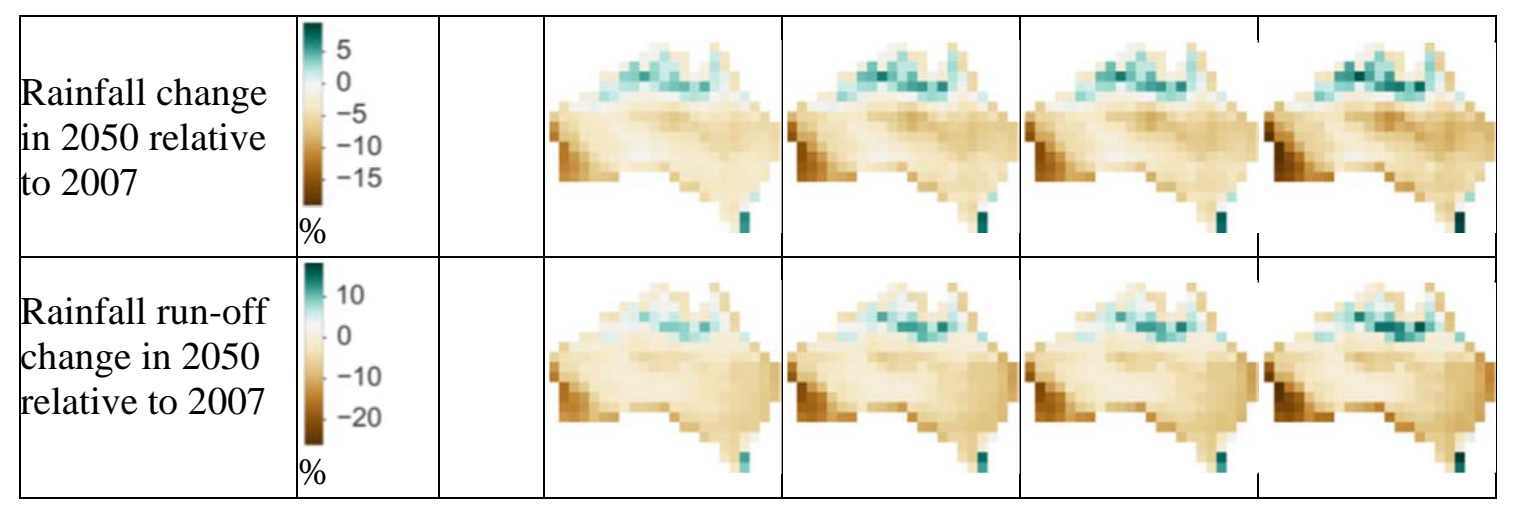


Supplementary Table 7 - Summary of mathematical notation.

\begin{tabular}{|c|c|c|c|}
\hline Variable name & Symbol & Units & Description \\
\hline \multicolumn{4}{|c|}{ Scenarios, variables, sets, and indices } \\
\hline Calendar year & $y$ & Year & Calendar year 2013 - 2050. \\
\hline Model year & $t, T$ & Year & $\begin{array}{l}\text { Each year } t \text { is a year in the rolling economic time horizon of } \\
T=100 \text { years. }\end{array}$ \\
\hline Discount rate & $r$ & $\%$ ра & $\begin{array}{l}\text { Discount rate used to calculate net present value of future } \\
\text { cash flow. Set at } 10 \% \text { pa. }\end{array}$ \\
\hline Global outlook & $o, O$ & - & $\begin{array}{l}\text { Each individual scenario } o \text { is used to iterate over the full set } \\
\text { of four scenarios } O\{\mathrm{~L} 1, \mathrm{M} 3, \mathrm{M} 2, \mathrm{H} 3\} \text {. }\end{array}$ \\
\hline $\begin{array}{l}\text { Adoption hurdle } \\
\text { rates }\end{array}$ & $h, H$ & Multiplier & $\begin{array}{l}\text { Each individual adoption hurdle rate } h \text { is used to iterate } \\
\text { over the full set of three land-use adoption hurdle rates } \\
H\{1 \times, 2 \times, 5 \times\} \text {. Indicates the number of times as profitable } \\
\text { reforestation land-uses need to be compared to agriculture } \\
\text { for land-use change to occur. }\end{array}$ \\
\hline $\begin{array}{l}\text { Agricultural } \\
\text { productivity rates }\end{array}$ & $u, U$ & $\begin{array}{l}\text { \% pa } \\
\text { simple } \\
\text { increase }\end{array}$ & $\begin{array}{l}\text { Each individual productivity rate } u \text { is used to iterate over } \\
\text { the full set of agricultural productivity rates } U\{0.0,1.5 \text {, } \\
3.0\} \text {. }\end{array}$ \\
\hline Land-uses & $\begin{array}{l}f, F \\
A G \\
E P, C P\end{array}$ & - & $\begin{array}{l}A G \text { is agriculture, } E P \text { is environmental plantings, and } C P \text { is } \\
\text { carbon plantings. } F \text { is the set of reforestation land-uses } \\
\{E P, C P\} \text { and } f \text { is used to iterate over } F \text {. }\end{array}$ \\
\hline $\begin{array}{l}\text { Multifunctionality } \\
\text { weights }\end{array}$ & $w, W$ & $\begin{array}{l}\text { weights } 0 \\
-1\end{array}$ & $\begin{array}{l}\text { Weights } w \text { in } W\{0.000,0.001,0.002, \ldots, 1.000\} \text { used to } \\
\text { find the optimal balance between carbon sequestration and } \\
\text { biodiversity co-benefits in calculating the index of } \\
\text { multifunctionality. }\end{array}$ \\
\hline Carbon levy & $i, I$ & $\%$ & $\begin{array}{l}\text { Carbon levy } i \text { in } I\{0,1,2, \ldots, 100 \%\} \text { is the levy applied to } \\
\text { CP. }\end{array}$ \\
\hline \multicolumn{4}{|l|}{ Model parameters } \\
\hline Carbon price & $p$ & $\$ \mathrm{tCO}_{2}^{-1}$ & Individual sale price of credits for carbon sequestration. \\
\hline $\begin{array}{l}\text { Annual carbon } \\
\text { sequestration }\end{array}$ & $\mathbf{c}(y)$ & $\begin{array}{l}\mathrm{tCO}_{2} \mathrm{ha}^{-1} \\
\mathrm{yr}^{-1}\end{array}$ & $\begin{array}{l}\text { Annual marginal carbon sequestration adjusted for risk and } \\
\text { climate change impacts. }\end{array}$ \\
\hline $\begin{array}{l}\text { Average annual } \\
\text { carbon } \\
\text { sequestration }\end{array}$ & $\overline{\mathbf{c}}(y)$ & $\mathrm{tCO}_{2} \mathrm{yr}^{-1}$ & $\begin{array}{l}\text { Annual carbon sequestration in forest stands averaged over } \\
100 \text { years of growth for each grid cell adjusted for risk and } \\
\text { climate change impacts. }\end{array}$ \\
\hline $\begin{array}{l}\text { Discounted } \\
\text { carbon } \\
\text { sequestration }\end{array}$ & $\mathbf{c}^{P V}(y)$ & $\mathrm{tCO}_{2}$ & $\begin{array}{l}\text { Annual marginal carbon sequestration of forest stands over } \\
100 \text { years of growth from year } y \text { for each grid cell adjusted } \\
\text { for risk and climate change impacts, and discounted to } \\
\text { present value terms. }\end{array}$ \\
\hline $\begin{array}{l}\text { Total costs of } \\
\text { reforestation }\end{array}$ & $\mathbf{P}(y)$ & $\$$ & $\begin{array}{l}\text { Total cost of reforestation to the landholder including direct } \\
\text { and opportunity costs (foregone net economic returns to }\end{array}$ \\
\hline
\end{tabular}




\begin{tabular}{|c|c|c|c|}
\hline & & & agriculture) discounted to present value terms. \\
\hline $\begin{array}{l}\text { Direct costs of } \\
\text { reforestation }\end{array}$ & $\mathbf{T C}(y)$ & $\$$ & $\begin{array}{l}\text { Direct costs of reforestation (superscripted }{ }^{f} \text { ) including } \\
\text { establishment, annual maintenance, transaction, and water } \\
\text { costs calculated over the } 100 \text { year horizon from year } y \text {, and } \\
\text { discounted to present value terms. }\end{array}$ \\
\hline $\begin{array}{l}\text { Net economic } \\
\text { returns }\end{array}$ & $\pi(y)$ & $\$$ & $\begin{array}{l}\text { Net economic returns to agriculture (superscripted }{ }^{A G} \text { ) and } \\
\text { reforestation (superscripted }{ }^{f} \text { ) calculated over the } 100 \text { year } \\
\text { horizon from year, and discounted to present value terms. }\end{array}$ \\
\hline Breakeven price & $\mathbf{p}(y)$ & \$ per unit & $\begin{array}{l}\text { The cost of supply of each unit of carbon sequestration and } \\
\text { biodiversity co-benefits (targeted separately and in } \\
\text { combination) required to change land-use. }\end{array}$ \\
\hline Area & $\mathbf{a}$ & ha & Total area of each grid cell. \\
\hline Biodiversity score & B & Index & $\begin{array}{l}\text { Biodiversity score layer reflecting the relative value of } \\
\text { reforestation for biodiversity. Superscripted } f \text { to indicate } \\
\text { reforestation type, the biodiversity score for CP is } 0 .\end{array}$ \\
\hline $\begin{array}{l}\text { Biodiversity co- } \\
\text { benefits }\end{array}$ & Bs & $\%$ of $\max$ & $\begin{array}{l}\text { Biodiversity score multiplied by grid cell area, divided by } \\
\text { the sum over all grid cells of the biodiversity score } \\
\text { multiplied by grid cell area. Superscripted } f \text { to indicate } \\
\text { reforestation type, the biodiversity co-benefits from CP is } 0 .\end{array}$ \\
\hline $\begin{array}{l}\text { Multifunctionality } \\
\text { weight }\end{array}$ & $w^{\prime}$ & $\begin{array}{l}\text { Weight } \\
0-1\end{array}$ & $\begin{array}{l}\text { Optimal weight used to balance carbon sequestration and } \\
\text { biodiversity co-benefits in calculating the index of } \\
\text { multifunctionality. }\end{array}$ \\
\hline Multifunctionality & $\mathbf{M}(y)$ & Index & $\begin{array}{l}\text { Weighted index maximising carbon sequestration and } \\
\text { biodiversity co-benefits produced by each grid cell. }\end{array}$ \\
\hline \multicolumn{4}{|l|}{ Model outputs } \\
\hline Potential land-use & $\mathbf{x}(y)$ & Binary & $\begin{array}{l}\text { Binary variables indicating the potential for agriculture } \\
\left(\text { superscripted }{ }^{A G} \text { ), carbon plantings (superscripted }{ }^{C P} \text { ), and }\right. \\
\text { environmental plantings (superscripted }{ }^{E P} \text { ). }\end{array}$ \\
\hline $\begin{array}{l}\text { Carbon } \\
\text { sequestration } \\
\text { supply }\end{array}$ & $\mathbf{S C}(y)$ & $\mathrm{tCO}_{2}$ & $\begin{array}{l}\text { Cumulative sum of average annual carbon sequestration } \\
\text { calculated over all grid cells and sorted by breakeven price. }\end{array}$ \\
\hline $\begin{array}{l}\text { Biodiversity co- } \\
\text { benefits supply }\end{array}$ & $\mathbf{S B}(y)$ & $\%$ & $\begin{array}{l}\text { Cumulative sum of biodiversity co-benefits calculated over } \\
\text { all grid cells and sorted by breakeven price. }\end{array}$ \\
\hline Budget & $\mathbf{Q}(y)$ & $\$$ & $\begin{array}{l}\text { Cumulative payment budget in net present value terms } \\
\text { calculated over all grid cells and sorted by breakeven price. }\end{array}$ \\
\hline $\begin{array}{l}\text { Budget } \\
\text { biodiversity } \\
\text { premium }\end{array}$ & $\mathbf{Q}^{B P}(y)$ & $\$$ & $\begin{array}{l}\text { Cumulative biodiversity premium payment budget in net } \\
\text { present value terms calculated over grid cells where CP } \\
\text { were the most profitable land-use, and sorted by cost- } \\
\text { effectiveness for delivering biodiversity co-benefits. }\end{array}$ \\
\hline $\begin{array}{l}\text { Reforestation } \\
\text { land-use }\end{array}$ & $\boldsymbol{\varphi}(y)$ & Binary & $\begin{array}{l}\text { Identifies those grid cells where the most profitable } \\
\text { reforestation land-use (i.e. CP or EP) was more profitable } \\
\text { than agriculture. }\end{array}$ \\
\hline
\end{tabular}




\begin{tabular}{|l|l|l|l|}
\hline Total budget & $Q(y)$ & $\$$ & $\begin{array}{l}\text { The total payment budget summed over grid cells whose } \\
\text { breakeven price was less than or equal to the global outlook } \\
\text { carbon price. }\end{array}$ \\
\hline $\begin{array}{l}\text { Carbon } \\
\text { sequestration } \\
\text { supply }\end{array}$ & $S C(y)$ & $\mathrm{tCO}_{2}$ & Total supply of carbon sequestration. \\
\hline $\begin{array}{l}\text { Biodiversity co- } \\
\text { benefits supply }\end{array}$ & $S B(y)$ & $\%$ & Total supply of biodiversity co-benefits. \\
\hline $\begin{array}{l}\text { Biodiversity } \\
\text { premium payment }\end{array}$ & $\Delta \boldsymbol{\pi}(y)$ & $\$$ & $\begin{array}{l}\text { Biodiversity premium payment (opportunity cost) of } \\
\text { adopting EP rather than CP, in present value terms. }\end{array}$ \\
\hline $\begin{array}{l}\text { Differential } \\
\text { carbon } \\
\text { sequestration }\end{array}$ & $\Delta \overline{\mathbf{c}}(y)$ & $\mathrm{tCO} 2$ & $\begin{array}{l}\text { The difference in average annual carbon sequestration } \\
\text { between CP and EP. }\end{array}$ \\
\hline $\begin{array}{l}\text { Cost- } \\
\text { effectiveness }\end{array}$ & $\mathbf{v}(y)$ & Index & $\begin{array}{l}\text { Index of cost-effectiveness for prioritising grid cells for } \\
\text { biodiversity premium payments. }\end{array}$ \\
\hline Carbon levy & $\mathbf{L}(y)$ & $\$$ & Carbon levy payable for CP. \\
\hline
\end{tabular}




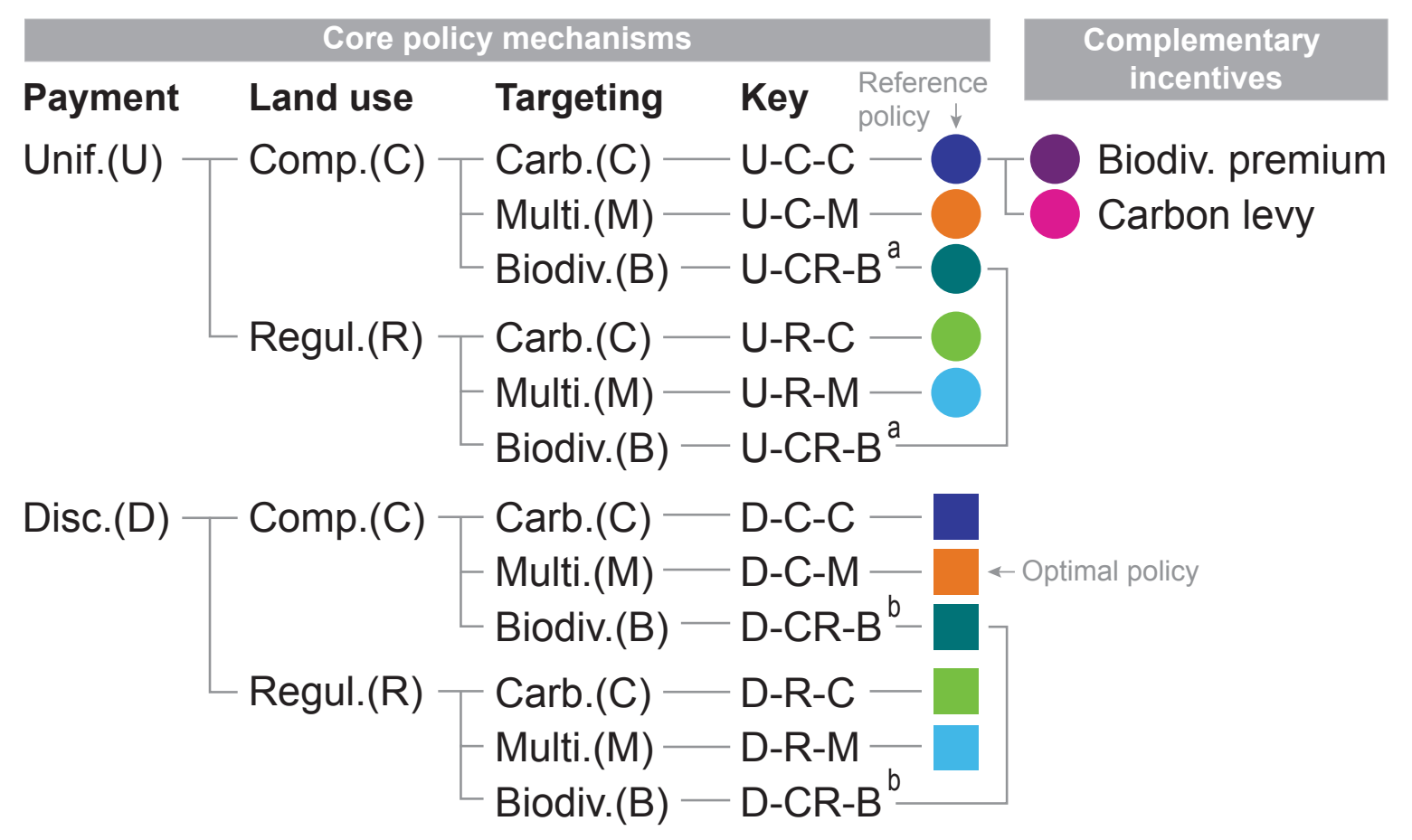


(x 100

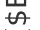

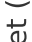

0
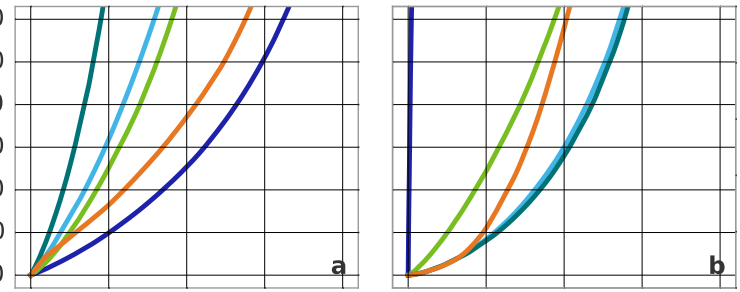

$\frac{\subseteq}{\frac{\subseteq}{3}}$

을
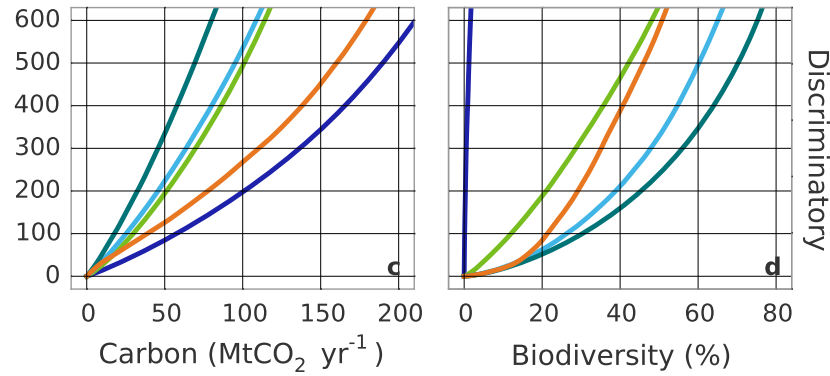

$\begin{array}{lllll}0 & 20 & 40 & 60 & 80\end{array}$

Biodiversity (\%)

Trade-offs

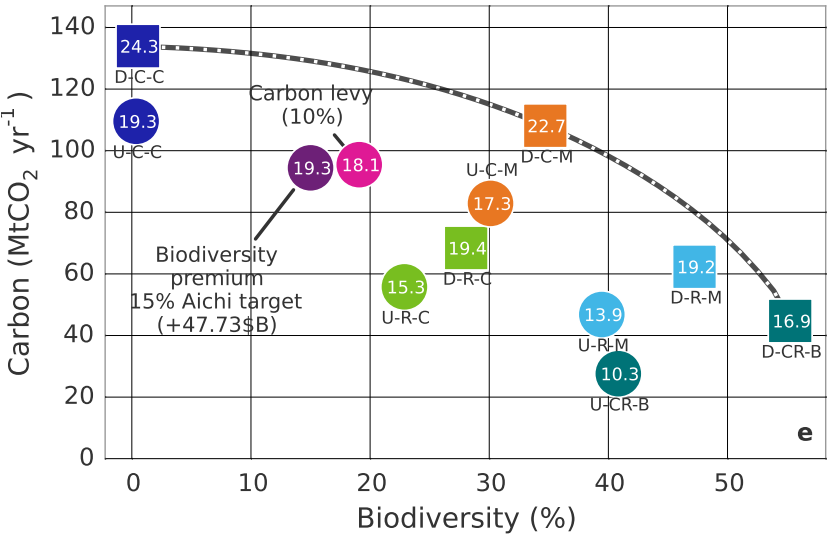


Policy mechanism: U-C-C

Carbon sequestration: $109.54 \mathrm{MtCO} 2 / \mathrm{yr}$

Biodiversity co-benefits: $0.36 \%$

Total area of reforestation: 19.31 Mha

Area of CP: $19.15 \mathrm{Mha}$

Area of EP: $0.16 \mathrm{Mha}$

Policy mechanism: D-C-M

Carbon sequestration: $108.09 \mathrm{MtCO} 2 / \mathrm{yr}$

Biodiversity co-benefits: $34.70 \%$

Total area of reforestation: $22.67 \mathrm{Mha}$

Area of CP: $13.71 \mathrm{Mha}$

Area of EP: 8.96 Mha

Agriculture

- Carbon plantings

— Environmental plantings 
Policy mechanism: U-C-C

Carbon sequestration: $109.54 \mathrm{MtCO} 2 / \mathrm{yr}$

Biodiversity co-benefits: $0.36 \%$

Total area of reforestation: 19.31 Mha

Area of CP: $19.15 \mathrm{Mha}$

Area of EP: $0.16 \mathrm{Mha}$

\section{a}

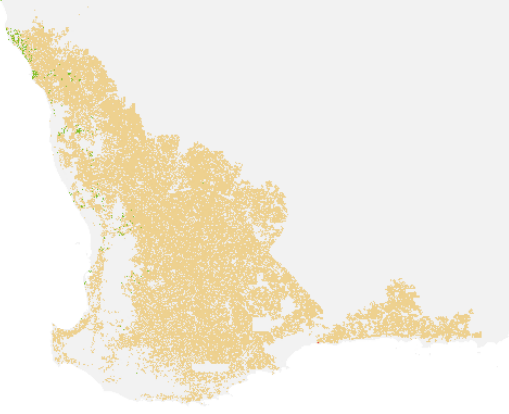

Policy mechanism: D-C-M

Carbon sequestration: 108.09 MtCO2/yr

Biodiversity co-benefits: $34.70 \%$

Total area of reforestation: $22.67 \mathrm{Mha}$

Area of CP: $13.71 \mathrm{Mha}$

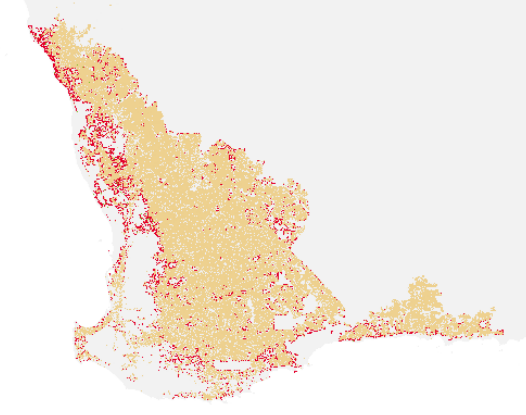

Area of EP: $8.96 \mathrm{Mha}$

\section{b}

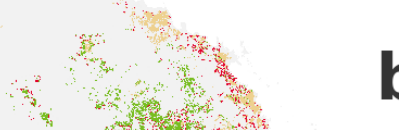

Agriculture

Carbon plantings

- Environmental plantings 


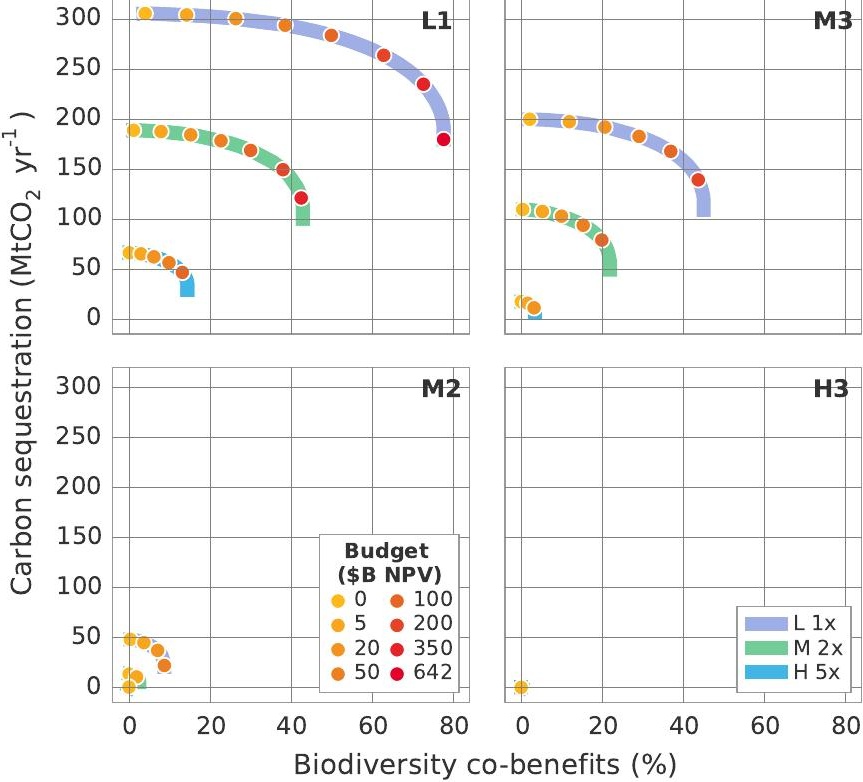




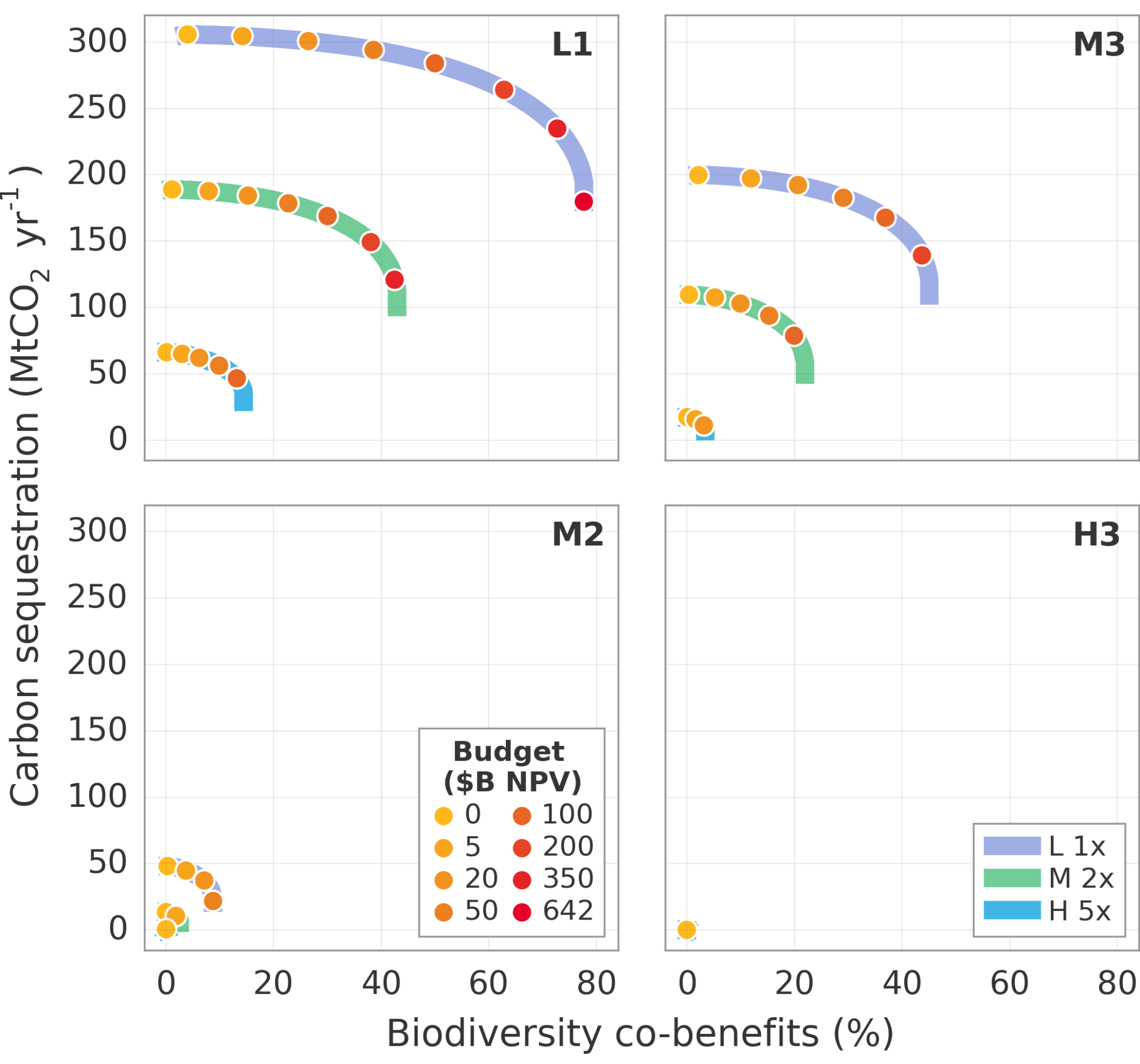




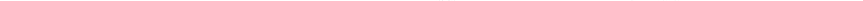




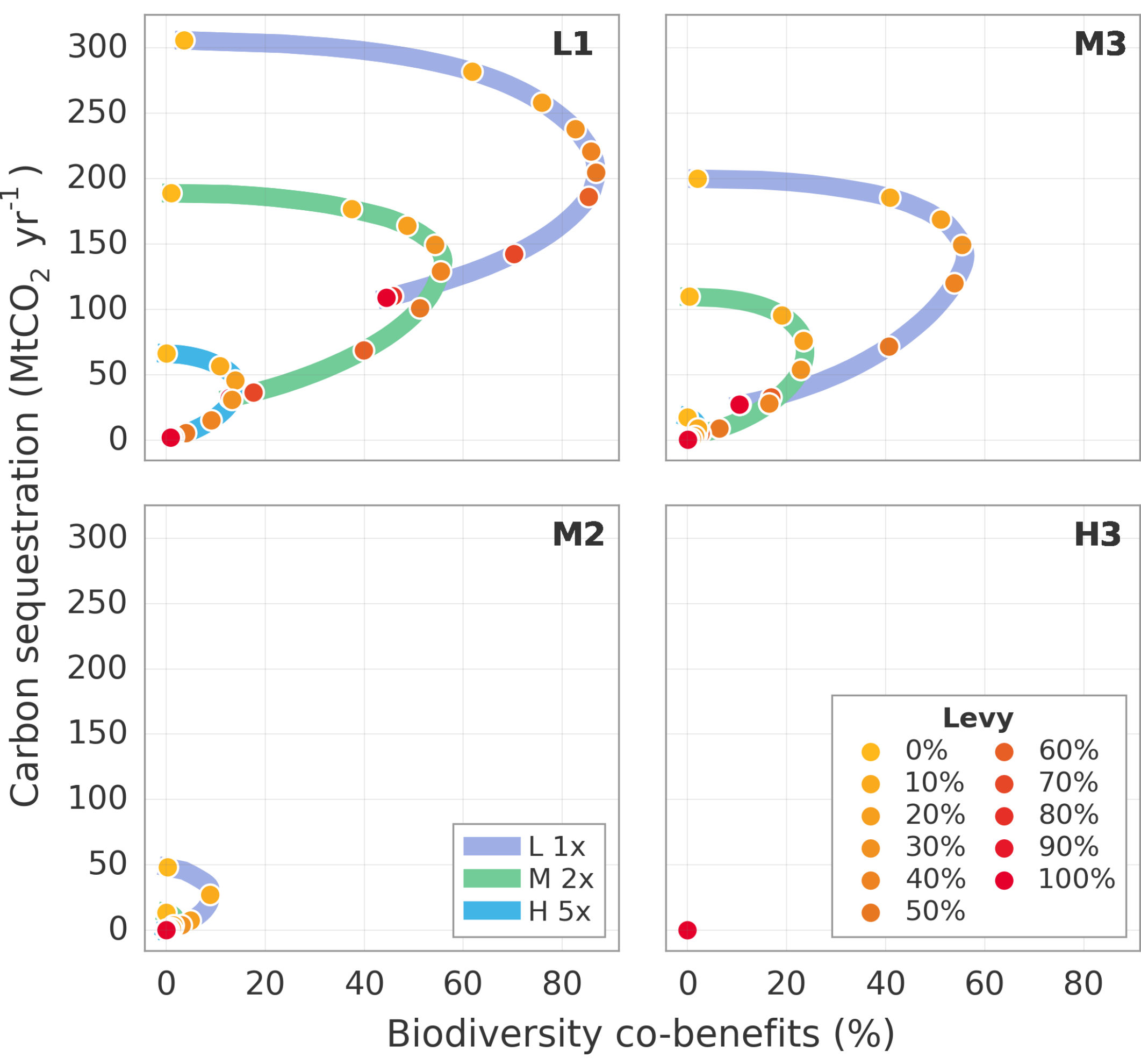

